\title{
Six new species of limoniid flies (Diptera: Limoniidae) from Tanzania and notes on other species new to the country's fauna
}

\author{
Шесть новых видов комаров-лимониид (Diptera: Limoniidae) \\ из Танзании и заметки о других видах, новых дмя фауны страны
}

\author{
D.I. Gavryushin \\ А.И. Гаврюшин
}

\begin{abstract}
Zoological Museum, Moscow Lomonosov State University, Bol'shaya Nikitskaya 2, Moscow 125009, Russia. E-mail: dmitry_gavryushin@yahoo.com

Зоологический музей, Московский государственный университет им. М.В. Ломоносова, Большая Никитская ул., 2, Москва 125009 Россия.
\end{abstract}

KEY WORDS: Diptera, Limoniidae, Chioneinae, Limnophilinae, Limoniinae, Trichotrimicra, Hexatoma, Medleromyia, Pilaria, Elephantomyia, Ellipteroides, Tanzania, Afrotropical region, taxonomy, description, new species, new records, new combination.

КЛЮЧЕВЫЕ СЛОВА: Diptera, Limoniidae, Limnophilinae, Chioneinae, Limnophilinae, Limoniinae, Trichotrimicra, Hexatoma, Medleromyia, Pilaria, Elephantomyia, Ellipteroides, Танзания, Афротропическая область, таксономия, описание, новый вид, новые находки, новая комбинация.

ABSTRACT. Six new species of limoniid flies (Diptera: Limoniidae) are described from Tanzania, Trichotrimicra mbeya, sp.n., Trichotrimicra odontocera, sp.n. (subfam. Chioneinae), Hexatoma (Eriocera) njombensis, sp.n., Medleromyia tanzanica, sp.n., Pilaria morogoroensis, sp.n. (subfam. Limnophilinae), and Elephantomyia (Elephantomyia) catarractes, sp.n. (subfam. Limoniinae). Thirteen species are recorded as new to the fauna of Tanzania. A new combination is established, Ellipteroides (Ellipteroides) difficilis (Alexander, 1920) (= Limnophila (Limnophila) difficilis Alexander, 1920), comb.n. Males of Orimarga (Orimarga) mashonensis Alexander, 1959 and Ellipteroides (Ellipteroides) difficilis (Alexander, 1920), comb.n. are described for the first time, male terminalia are illustrated.

РЕЗЮМЕ. Шесть новых видов комаров-лимониид (Diptera: Limoniidae) описаны из Танзании: Trichotrimicra mbeya, sp.n., Trichotrimicra odontocera, sp.n. (подсем. Chioneinae), Hexatoma (Eriocera) njombensis, sp.n., Medleromyia tanzanica, sp.n., Pilaria morogoroensis, sp.n. (подсем. Limnophilinae), и Elephantomyia (Elephantomyia) catarractes, sp.n. (подсем. Limoniinae). Тринадцать видов впервые указываются для фауны Танзании. Установлена новая комбинация, Ellipteroides (Ellipteroides) difficilis (Alexander, 1920) = Limnophila (Limnophila) difficilis Alexander, 1920, comb.n. Впервые описаны самцы Orimarga (Orimarga) mashonensis Alexander, 1959 и Ellipteroides (Ellipteroides) difficilis (Alexander, 1920), comb.n., даны иллюстрации терминалий самцов .

\section{Introduction}

Fifty-one species of limoniid flies have been recorded from Tanzania so far [Oosterbroek, 2016], mostly through the efforts of Charles P. Alexander who published an extensive study of the crane-flies collected by the Ruwenzori Expedition of the British Museum of Natural History in 1934-35 [Alexander, 1956]. This number shows that crane-flies are being vastly undercollected in Tanzania which is true for most tropical countries of the world. The author had an opportunity to examine specimens of limoniid flies collected by Nikita E. Vikhrev in Tanzania in December, 2015; this resulted in the discovery of three species new to science which are described below. Numerous specimens collected by the author in Tanzania in September, 2012 (yet only partially examined) contained three more species new to science, their descriptions also are given below. Additionally, this material included more species representing new records for the fauna of Tanzania.

\section{Material and methods}

The morphological terms used here mainly follow McAlpine [1981], venation is described mostly after Alexander and Byers [1981]. Male genitalia were boiled in $10 \%$ solution of potassium hydroxide $(\mathrm{KOH})$ for 60 to $90 \mathrm{~s}$, neutralised by a $10 \%$ solution of acetic acid $(\mathrm{CH} 3 \mathrm{COOH})$, rinsed in water and then stored in glycerol. Dissected male genitalia were examined with a Nikon SMZ645 binocular microscope and then photographed using an eTREK DCM900 camera on MBI-1 

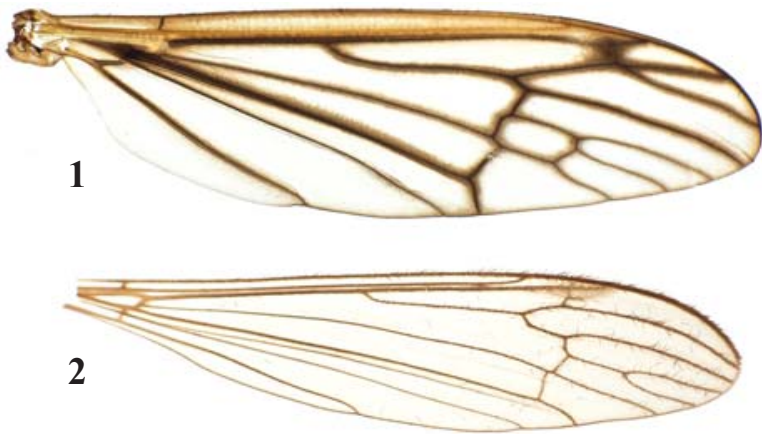

3

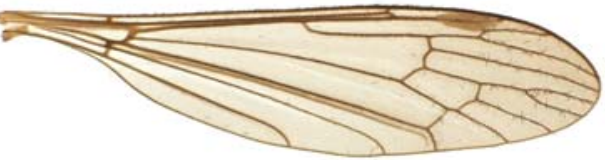

4

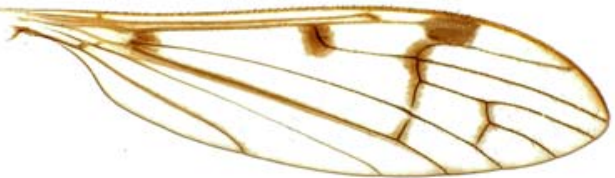

5

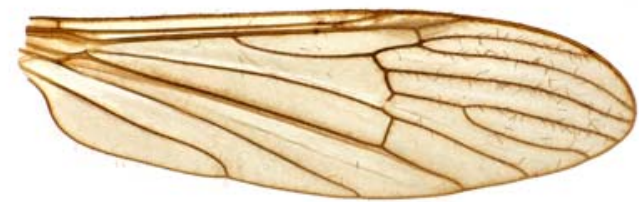

6

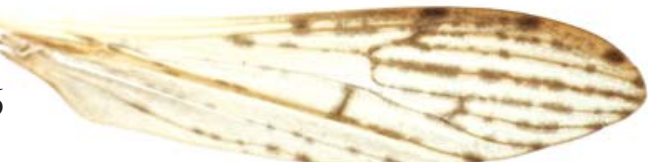

7

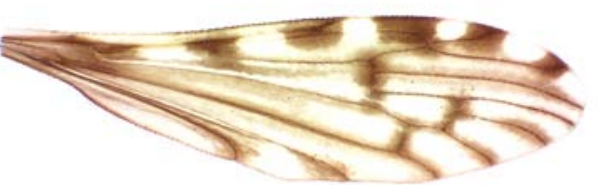

Figs 1-7. Right wings of Limoniidae males: $1-$ Hexatoma (Eriocera) njombensis sp.n., ; 2 - Medleromyia tanzanica $\mathbf{\text { sp.n.; } 3}$ - Pilaria morogoroensis sp.n.; 4 - Elephantomyia (Elephantomyia) catarractes sp.n.; 5 - Ellipteroides (Ellipteroides) difficilis comb.n.; 6 - Erioptera (Erioptera) subirrorata; 7 - Trichoneura (Ceratolimnobia) munroi; 1-4 - holotypes. Not to the same scale.

Рис. 1-7. Правые крылья самцов комаров-лимониид: 1 Hexatoma (Eriocera) njombensis sp.n.; 2 - Medleromyia tanzanica sp.n.; 3 - Pilaria morogoroensis sp.n.; 4 - Elephantomyia (Elephantomyia) catarractes sp.n.; 5 - Ellipteroides (Ellipteroides) difficilis comb.n.; 6 - Erioptera (Erioptera) subirrorata; 7 Trichoneura (Ceratolimnobia) munroi; 1-4 - голотипы. Масштаб разный.

microscope; images were processed with CombineZP software by Alan Hadley (http://www.hadleyweb. pwp.blueyonder.co.uk). Wings were photographed with a Nikon D70s DSLR camera. Type material is deposited in the Zoological Museum of the Moscow State University (ZMMU).
Taxonomic part

Descriptions of new species

Subfamily Chioneinae

Trichotrimicra mbeya, sp.n.

Figs 8-12.

MATERIAL EXAMINED. Holotype, $\sigma^{7}$, TANZANIA, Mbeya Range, $8.85^{\circ} \mathrm{S}, 33.50^{\circ} \mathrm{E}, 2300 \mathrm{~m}$ a.s.1., $12 . X \mathrm{XI} .2015$, N. Vikhrev leg.

DIAGNOSIS. Small, yellowish brown fly of appearance typical for the genus. Antennal verticils up to 3.5 times longer than segments; prescutum unpatterned; legs dull yellow; outer gonostylus of male hypopygium deeply forked, outer angle of its inner arm with a powerful spine; parameres appearing as curved dark spines.

DESCRIPTION. Male. Measurements. Body length, 3 $\mathrm{mm}$, wing length, $4.5 \mathrm{~mm}$. Head brown with yellowish pruinosity. Rostrum yellow, palpi dark brown. Antennae brown, three basal flagellomeres very short-oval, distal flagellomeres more elongate-oval, becoming long and narrow at the apex. Verticils very long, on medial flagellomeres 3.5 times longer than segments.

Thorax: general colouration yellowish brown, thorax subshining, without distinct spots or stripes. Halteres dull yellow. Legs (only left mid leg remaining) dull yellow throughout. Several yellow hairs on posterior borders of anepisternum and metepisternum. Abdomen yellowish brown, with long yellow hairs.

Wings weakly tinged with yellowish brown; stigma absent; macrotrichia in all cells, more abundant beyond cord; veins near wing base, $C$ and $S c$ brownish yellow, the rest brown. Venation: $S c_{1}$ ends at two-thirds of $R s, S c_{2}$ removed, at roughly 0.35 length of $R s ; R s$ long, straight, approx. 3.5 times longer than $R_{2+3+4} ; R_{1+2}$ almost 3 times longer than $R_{2}$, its tip upcurved; $R_{2}$ on $R_{3}$, approx. three-fourths its own length beyond the fork of $R_{3+4} ; R_{2+3+4}$ oblique, longer than $R_{2}$; veins $R_{3}$ and $R_{4}$ slightly divergent, distal section of $M_{1+2}$ weakly upcurved, cells $2 r_{1}$ and $r_{2}$ subequal in width, $r_{2}$ wider than $r_{3}$, $r_{3}$ twice wider than $r_{5}$; basal section of $R_{5}$ almost transverse, 1.5 times shorter than $R_{2+3+4} ; R_{5}$ slightly curved downwards at wing margin; cell $d m$ pentagonal, widened posteriorly, small, almost twice shorter than the distal section of $C u A_{1}$, much shorter than $M_{3}$ and $M_{1+2}$; basal section of $C u A_{1}$ oblique, twice $r-m, 2.5$ times shorter than $C u A_{2}$, approx. one-third its own length before the fork of $M$. Vein $A_{1}$ ends opposite the level of the fork of $R s, A_{2}$ near the level of origin of $R s$.

Abdomen yellowish brown, with long yellow hairs. Hypopygium (Figs 8-9) with gonocoxite elongate-cylindrical, narrowed distally; outer gonostylus about two-thirds the length of gonocoxite, deeply forked, its curved outer arm a short obtuse blade, less pigmented inner arm bent into a wide subtriangular lobe, outer angle of inner arm with a stout dark spine (best seen in caudal view, Fig. 10); inner gonostylus about two-thirds the length of outer one, slightly curved, tip widely rounded; aedeagal complex (Figs 11-12) large, much like in T. medleri, penis relatively short, its tip greatly widened and deeply bifid, parameres appearing as curved dark spines, vesica large, oval, lateral apodemes of vesica welldeveloped.

Female unknown.

DISTRIBUTION. Tanzania.

ETYMOLOGY. The species is named after the Mbeya Range, a mountain range in southwestern Tanzania (Mbeya Region, highest point, $2565 \mathrm{~m}$ a.s.l.), the location where it was collected. 

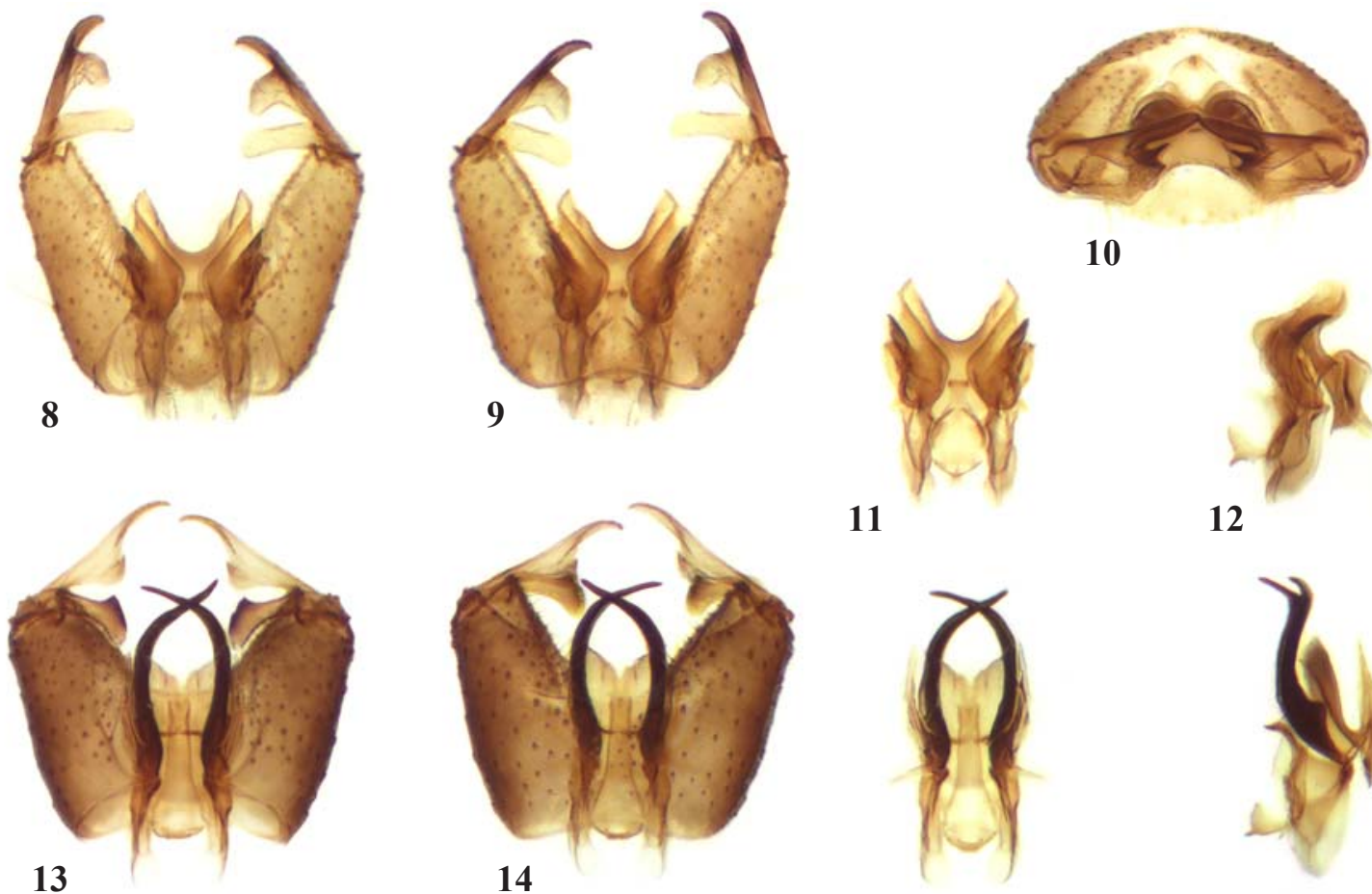

10

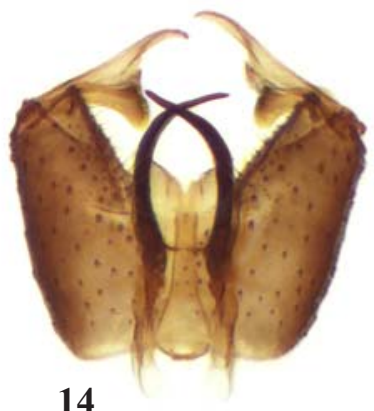

11
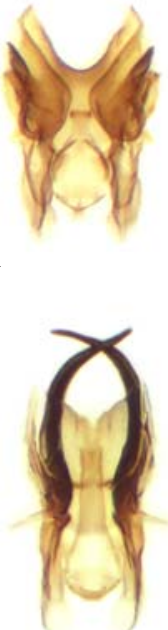

16

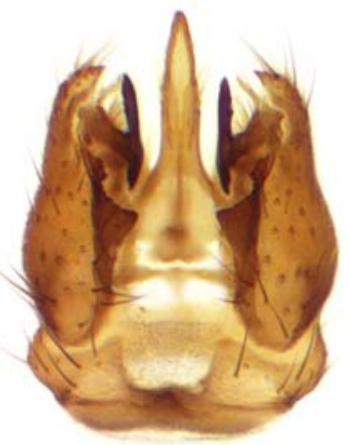

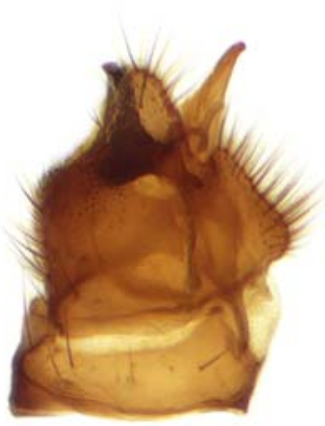

19

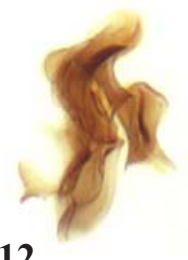

12

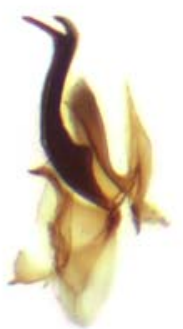

17

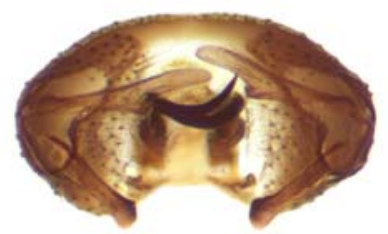

15
18
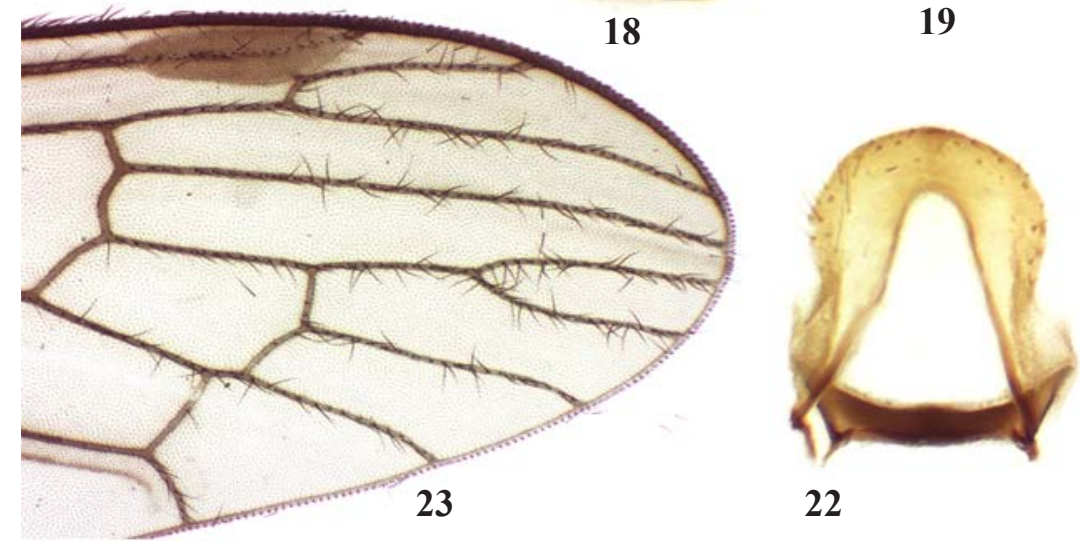

22

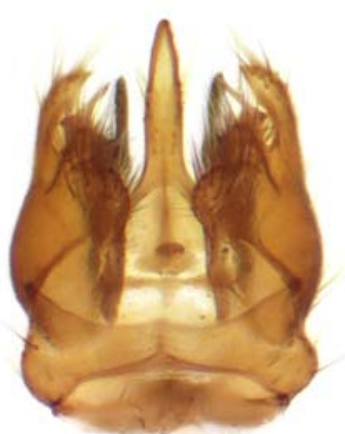

20

Figs 8-23. Trichotrimicra mbeya sp.n., holotype $0^{7}: 8$ - hypopygium, dorsal view; 9 - same, ventral view; 10 - same, caudal view; 11 - aedeagal complex, ventral view; 12 - same, lateral view; Trichotrimicra odontocera sp.n., holotype $\sigma^{7}: 13$ - hypopygium, dorsal view; 14 - same, ventral view; 15 - same, caudal view; 16 - aedeagal complex, dorsal view; 17 - same, lateral view; Ellipteroides (Ellipteroides) difficilis comb.n., male: 18 - hypopygium, dorsal view; 19 - same, lateral view; 20 - same, ventral view; 21 - same, caudal view; 22 abdominal segment 8, ventral view; Pilaria morogoroensis sp.n., holotype $\sigma^{7}: 23$ - apex of right wing. Not to the same scale.

Рис. 8-23. Trichotrimicra mbeya sp.n., голотип о': 8 - гипопигий, вид сверху; 9 - то же, вид снизу; 10 - то же, вид сзади; 11 эдеагус, вид снизу; 12 — то же, вид сбоку; Trichotrimicra odontocera sp.n., голотип О': 13 — гипопигий, вид сверху; 14 - то же, вид снизу; 15 - то же, вид сзади; 16 — эдеагус, вид сверху; 17 — то же, вид сбоку; Ellipteroides (Ellipteroides) difficilis comb.n., о: 18 гипопигий, вид сверху; 19 - то же, вид сбоку; 20 — то же, вид снизу; 21 — то же, вид сзади; 22 - 8-й сегмент брюшка, вид снизу; Pilaria morogoroensis sp.n., голотип о: 23 - вершина правого крыла. Масштаб разный. 
DISCUSSION. Among the species of the genus described from males, the new species is similar to Trichotrimicra medleri Alexander, 1974, differing in details of colouration, wing venation, and structure of male hypopygium, especially inner gonostylus. Of the species described from females, $T$. flavidella Alexander, 1972 is generally yellow, T. majuscula (Alexander, 1956) is mostly dark brown and much larger.

\section{Trichotrimicra odontocera, sp.n.} Figs 13-17.

MATERIAL EXAMINED. Holotype, $\sigma^{\top}$, TANZANIA, Mbeya Range, $8.85^{\circ} \mathrm{S}, 33.50^{\circ} \mathrm{E}, 2300 \mathrm{~m}$ a.s.1., 12.XII.2015, N. Vikhrev leg. Paratype, $\sigma^{7}$, same location and data.

DIAGNOSIS. Small, yellowish brown fly of appearance typical for the genus. Antennal verticils less than twice the length of segments; prescutum with three indistinct brown stripes; legs mostly brown; outer gonostylus of male hypopygium pale, forked, its inner arm tapering into a short spine; inner arms of parameres are powerful blackened spines, strongly curved and overlapping each other apically.

DESCRIPTION. Male. Measurements. Body length, 3 $\mathrm{mm}$, wing length, $4.2-4.5 \mathrm{~mm}$. Differs from Trichotrimicra mbeya, sp.n., in the following:

Rostrum dark brown; antennae with verticils shorter, at most less than twice the length of segments; prescutum with three indistinct confluent brown stripes, the median one wider and longer; sides of prescutum yellowed; halteres infuscated, only extreme base of stem yellow; legs with coxae, trochanters and bases of femora dull yellow, remainder of legs brown, tips of tarsi darkened; wings more distinctly tinged with brown; $S c$ at midlength of $R s$; tips of $R_{5}$ and $M_{1+2}$ are parallel so cell $r_{3}$ a little wider than $r_{5}$; cell $d m$ more narrow; $A_{2}$ ends before the level of origin of $R s$; the basal section of $R_{5}$ and $r-m$ almost in transverse alignment; abdominal tergites yellowish brown, darker laterally, sternites more yellowed. Hypopygium (Figs 13-17) with outer gonostylus pale, forked, its outer arm a weakly curved blade with obtuse tip, inner arm a short lobe tapering into a short spine; inner gonostylus shorter, more pigmented, apex sclerotised, weakly forked, outer arm very short, subacute, inner arm an obtuse lobe; penis very short, straight, parameres with outer arms bifid, ventral portions fused, forming an emarginated plate above penis, dorsal portions slender, gently curved, triangular, produced into long acute tips; inner arms of parameres are powerful blackened spines, strongly curved and overlapping each other apically; vesica suboval, lateral apodemes well-developed, wide.

Female unknown.

DISTRIBUTION. Tanzania.

ETYMOLOGY. The species name (adj., fem. sing.) is

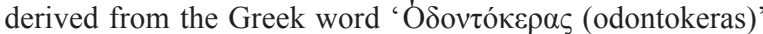
meaning 'tusk', referring to parameres that resemble elephant's tusks in shape.

DISCUSSION. Similar in appearance to Trichotrimicra mbeya, sp.n., differing in details of structure of antennae, colouration of prescutum and legs, wing venation, and especially structure of male hypopygium.

DISTRIBUTION. Tanzania.

\section{Subfamily Limnophilinae \\ Hexatoma (Eriocera) njombensis, sp.n.} Figs 1, 24-31.

MATERIAL EXAMINED. Holotype, $\sigma^{7}$, TANZANIA, $40 \mathrm{~km}$ $\mathrm{SE}$ of Njombe, $9.52^{\circ} \mathrm{S}, 35.09^{\circ} \mathrm{E}, 1700 \mathrm{~m}$ a.s.1., 17.XII.2015, N Vikhrev leg.

DIAGNOSIS. Large, male antennae greatly elongated, more than twice longer than wing, most of the veins narrowly bordered with brown, $R$, its own length before the fork of $R_{3+4}$, cell $m_{1}$ lacking.

DESCRIPTION. Male. Measurements. Body length, 13 $\mathrm{mm}$, wing length, $16 \mathrm{~mm}$, antenna (longest remaining part), $35 \mathrm{~mm}, 1^{\text {st }}$ flagellomere, $5 \mathrm{~mm}, 2^{\text {nd }}$ flagellomere, $6 \mathrm{~mm}, 3^{\text {rd }}$ flagellomere, $11 \mathrm{~mm}, 4^{\text {th }}$ flagellomere, $10 \mathrm{~mm}$. Head reddish yellow, with a large tubercle which is entire, rounded, without spots, its hight subequal to that of head. Rostrum and palpi reduced, dark brown. Antennae apparently 7-segmented (left antenna, broken below the base of the $4^{\text {th }}$ flagellomere; right antenna, broken near one-third the length of the $3^{\text {rd }}$ flagellomere), greatly elongated (more than twice exceeding the length of wing, nearly 3 times longer than body), with scape reddish yellow, long (approx. 3 times longer than pedicel), pedicel brownish yellow, flagellomeres brownish black. All flagellomeres with emergence setae, about 10 on the $1^{\text {st }}$ flagellomere, 15 on the $2^{\text {nd }}$ flagellomere, 25 on the $3^{\text {rd }}$ flagellomere.

Thorax with prescutum brown with grey pruinosity, four conspicuous brown stripes of which the median pair is the longest and confluent anteriorly, medio-lateral stripes continuing on the scutal lobes. Mediotergite reddish, darkened laterally. Pleurae reddish brown, without distinct spots or stripes, grey pruinose, laterotergites mostly reddish. Vestiture consists of yellowish hairs, more abundant on posterior surface of head tubercle, occiput, interspaces of prescutum, posterior edges of scutal lobes, mediotergite, coxae, and lateral areas of abdomen. Halteres with stems reddish brown, apical sixth and knobs infuscated. Legs with coxae brownish yellow, grey pruinose (especially fore and mid coxae), trochanters reddish yellow, the rest uniformly brownish black, without any rings or pattern.

Wings (Fig. 1) rather broad, tinged with yellow, glabrous. Costa partially yellow (extreme base and area between origin of $R S$ and tip of $R_{1+2}$ ), vein $S c$ completely yellow (including $S c_{2}$ ), arculus and extreme bases of $R$ and $A_{2}$ also yellow; the remaining veins brown, including the humeral vein. All longitudinal veins and cross-veins except $C, S c, S c_{2}, R$ narrowly seamed with brown, the seams rather faint on distal sections of branches of $M$, distal section of $C u A_{1}$, and $A_{1}$. A short brown longitudinal streak in the prearcular field. Venation: $S c_{1}$ ending at 0.6 length of $R_{2+3+4}, S c_{2}$ removed from tip of $S c_{1}$, shortly beyond the level of fork of $R s$; vein $S c_{1}$ subequal to $R_{1+2}$; origin of $R s$ at approx. 0.4 length of wing, $R s$ long, equal to $R_{5} ; R_{1+2}$ approx. 1.5 times longer than $R_{2}$, its tip weakly upcurved; $R_{2}$ its own length before the fork of $R_{3+4}$, $R_{3+4}$ longer than $R_{2}$; basal section of $R_{5}$ oblique, subequal to $R_{2}^{3+4} ; r-m$ cross-vein oblique, 1.5 times longer than the basal section of $R_{5}$; cell $\mathrm{dm}$ longer than the distal section of $\mathrm{Cu} \mathrm{A}_{1}$; basal section of $C u A_{1}$ oblique, in alignment with $r-m$, twice longer than the basal section of $R_{5}$ and longer than $C u A_{2}$. Vein $M$ in one wing with a short spur jutting into cell $b r$ approx. at midlength of $R s$; most probably an adventitious character although recorded in several regional species. $\mathrm{CuA}$, strongly bent caudad, almost transverse, its end close to the end of $A_{1}$, the distance between them subequal to length of $C u A_{2}$. Vein $A_{2}$ ends shortly before the level of origin of $R s$.

Abdomen yellowish brown, $2^{\text {nd }}$ tergite more yellowed, sternites with an indistinct brown median line. Tergite 8 (Fig. 27) much shorter than sternite 8 , deeply bilobed. Hypopygium (Figs 24-26) large, with segment 9 rectangular, wider than long, anterolateral borders slightly convex, posterior border of tergite 9 with deep triangular emargination, anterior border concave; gonocoxite large, elongatecylindrical, gently curved; outer gonostylus heavily pigmented, almost cylindrical, tapering into a short acute tip, 
ventral surface before the tip weakly serrate, its distal twothirds densely covered with microscopic spinulae; inner gonostylus shorter and much stouter, with a large subapical triangular projection ventrally (best seen in caudal view, Fig. 26), at apex bent into a short obtuse tip bearing 2-3 apical setae, with a thick longitudinal ridge extending from the posterior to dorsal surface and ending shortly before apex, the ridge bearing long hairs on both surfaces, additional numerous fold-like lines on the dorsal surface of inner gonostylus, the surface of inner gonostylus outside the ridge with microscopic spinulae; proctiger well-developed, a scabrous two-layered membranous structure with lateral fold; aedeagal complex (Figs 28-31) large, parameres apparently bipartite, basal portions massive, distal portions with bases fused medially forming a bridge, posterodorsal corners produced into a subtriangular blade with semicircular perforation, posteroventral corners with a large obtuse lobe produced mesad, a few short dark spines near its apex
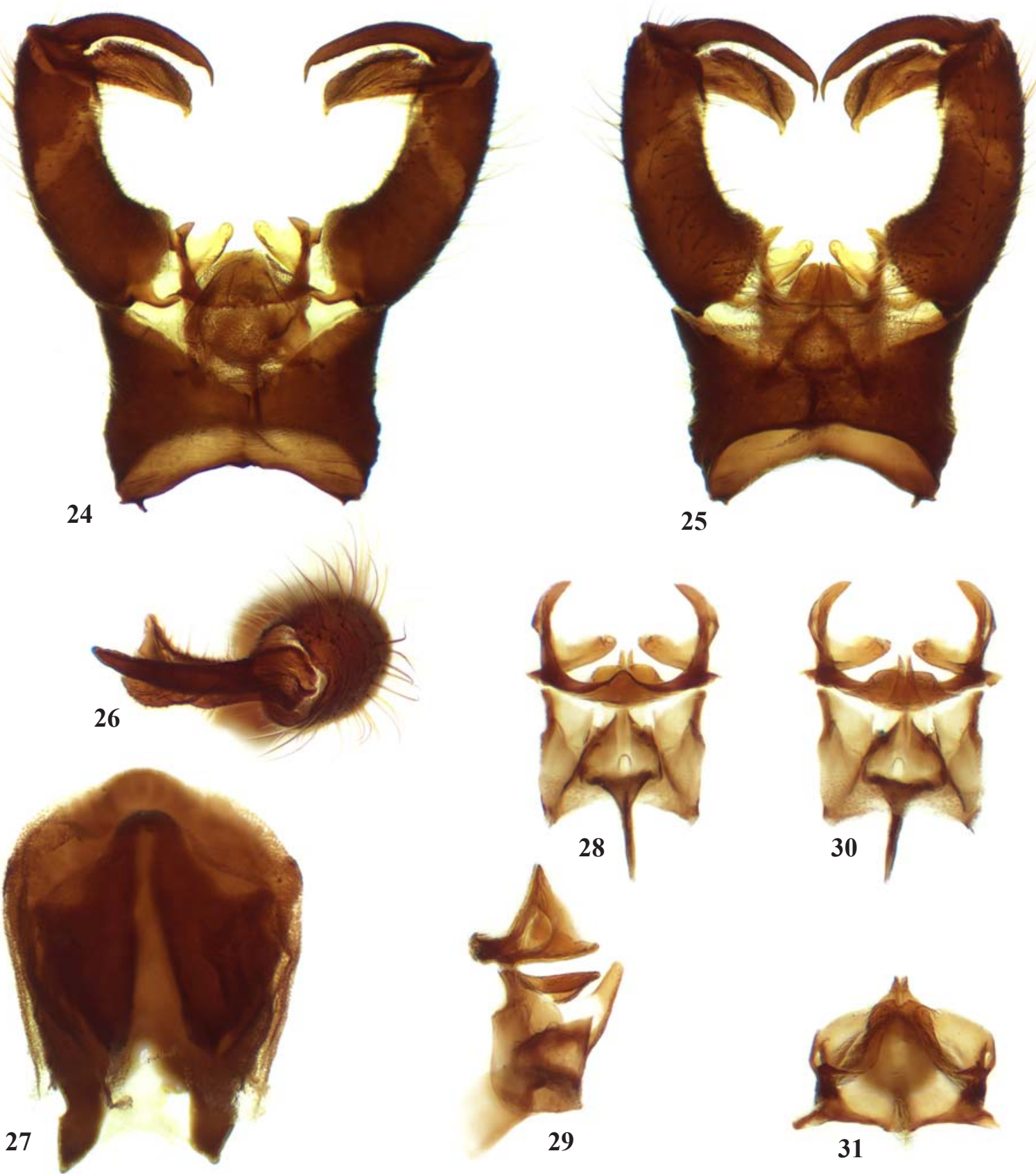

Figs 24-31. Hexatoma (Eriocera) njombensis sp.n., holotype $0^{7}$ : 24 - hypopygium, dorsal view; 25 - same, ventral view; 26 gonopod, caudal view; 27 - abdominal segment 8, dorsal view; 28 - aedeagal complex, dorsal view; 29 - same, lateral view; 30 - same, ventral view; 31 - same, caudal view. Not to the same scale.

Рис. 24-31. Hexatoma (Eriocera) njombensis sp.n., голотип О’: 24 - гипопигий, вид сверху; 25 - то же, вид снизу; 26 гоноподит, вид сверху; 27 - 8 -й сегмент брюшка, вид сверху; 28 — эдеагус, вид сверху; 29 — то же, вид сбоку; 30 — то же, вид снизу; 31 - то же, вид сзади. Масштаб разный. 
dorsally; penis short, deeply bifid, vesica large, semi-oval, dorsal apodeme of vesica very long, strongly compressed.

Female unknown.

DISTRIBUTION. Tanzania.

ETYMOLOGY. Named after Njombe, a town in southern Tanzania (Njombe Region) that is closest to the type location.

DISCUSSION. By Alexander's key to the Afrotropical species of Hexatoma [Alexander, 1956: 295-297], the present fly runs to Hexatoma (Eriocera) brevifurca Alexander, 1956 (Uganda), a much smaller and entirely different insect, with three prescutal stripes, dark brown trochanters, etc. Using the same author's key to the South African species [Alexander, 1964: 364], the present fly runs to $H$. (E.) preposita Alexander, 1956, an entirely different species in many respects. Another species with greatly elongated male antennae and vein $R_{2}$ far before the fork of $R_{3+4}, H$. (E.) dysantes Alexander, 1951 (Madagascar), has thorax uniformly brownish black and glabrous, legs with femora and tibiae obscure yellow, the tips narrowly darkened, etc. [Alexander, 1951]. Finally, none of the regional species of Hexatoma (Eriocera) discovered so far has legs with femora, tibiae, and tarsi uniformly brownish black.

\section{DISTRIBUTION. Tanzania.}

\section{Medleromyia tanzanica, sp.n.} Figs 2, 32-38.

MATERIAL EXAMINED. $10^{7}$, TANZANIA, Morogoro env., Uluguru Mts, $6.84593^{\circ} \mathrm{S}, 37.692^{\circ} \mathrm{E}, 853 \mathrm{~m}$ a.s.1., 17.IX.2012, D. Gavryushin leg.

DIAGNOSIS. A crane-fly of moderate size with general colouration brownish yellow and tarsi mainly white; a short spur of $R_{3}$ preserved; cell $d m$ open by the atrophy of the basal section of $M_{3}$; male hypopygium with the posterior border of tergite 9 narrowly emarginated, the emargination with a single lobe on either side, dorsomesal surface of gonocoxite with rectangular glabrous tubercle near midlength, outer gonostylus a short glabrous rod, inner gonostylus of complex structure, parameres bent into a U-shape distally.

DESCRIPTION. Male. Measurements. Body length, 6 $\mathrm{mm}$, wing length, $6.5 \mathrm{~mm}$. Head brown above, yellow below. Rostrum and palpi yellow brown. Antennae 16segmented, with scape and pedicel yellow, flagellomeres brown; flagellomeres elongate-oval except 2 and 3 which are very short-oval, verticils longer than segments.

Thorax with thoracic dorsum almost uniformly brownish yellow, pleurae clearer yellow. Halteres yellowish brown, with knobs darker. Legs with coxae and trochanters yellow, bases of femora narrowly yellow, tibiae and proximal parts of basitarsi brown, distal parts of basitarsi (one-third in fore and mid tarsi, two-thirds in hind tarsi) and remaining tarsomeres white; a small blackened tibial spur on each leg.

Wings (Fig. 2) with brownish tinge, iridescent, stigma faint. Venation: $S c_{1}$ ends at the level of fork of $R S, S c_{2}$ removed, $S c_{1}$ alone subequal to $R_{2+3+4} ; R_{1+2}$ more than 3 times longer than $R_{2} ; R_{2}$ transverse, in right wing subequal to $R_{2+3}$, in left shorter than $R_{2+3} ; R_{3}$ remarkably reduced to a short spur, in right wing it's half the length of $R_{1+2}$, in left wing two-thirds $R_{1+2} ; R_{4}$ strongly curved so cell $r_{2+3}$ more than 3 times wider than $r_{4}$ at wing margin; basal section of $R_{5}$ slightly angulated at one-fourth its length, longer than $R_{2+3+4}$; cell $d m$ open by atrophy of basal section of $M_{3}$; cell $m_{2}$ longer than its petiole; basal section of $C u A_{1}$ about onethird its length before the fork of $M$, shorter than $\mathrm{CuA}$. $\mathrm{CuP}$ distinct. Veins $R, R s, R_{1}, M, C u A$, tip of $A_{1}$ and longitudinal veins beyond cord, including spur of $R_{3}$, with long macrotrichia.

Abdomen yellow brown, sternites brown laterally. Hypopygium (Figs 32-36) with tergite 9 transverse, more than twice as wide as it's long, posterior border with a relatively narrow U-shaped emargination, on either side of which with a single lobe covered with numerous setae on dorsal and mesal surfaces; gonocoxite cylindrical, near midlength on dorsomesal surface with rectangular glabrous tubercle; outer gonostylus a short glabrous rod, slightly dilated at outer end, tip acute; inner gonostylus large, about three-fourths the length of gonocoxite, subrectangular in caudal view (Fig. 34), suboval in lateral view, gently curved, tip obtuse, anterior surface emarginate with more pigmented flange, setae relatively scarce, mainly on dorsal surface and, less evidently, anterior surface within the emargination. Proctiger distinct, a subtriangular multi-layered membraneous structure. Aedeagal complex (Figs 36-38): parameres with inner arms appearing as strongly decurved divergent slender rods, beyond midlength each with a small dorsal lobe, more distally each bent laterad and then mesad forming a U-shaped structure, tips obtuse; outer arms paler, subtriangular, fused medially, posteroventral corners produced into short subtriangular lobes. Penis short, deeply bifid, vesica small, lateral apodemes of vesica short and stout.

Female unknown

DISTRIBUTION. Tanzania.

ETYMOLOGY. The name (adj., fem. sing.) is derived from the country's name, Tanzania.

DISCUSSION. Medleromyia tanzanica, sp.n. undoubtedly belongs to the genus Medleromyia Alexander, 1974, generally agreeing with $M$. nigeriana in the structure of male hypopygium yet different in many respects, especially in details of tergite 9, gonocoxite, inner gonostylus, and parameres. The new species considerably differs from the two previously described species of Medleromyia in wing venation, having the vein $R_{3}$ preserved as a short spur. Both of these two species have two branches of $R s$ and no trace of vein $R_{3}$, cell $d m$ open by the atrophy of the basal section of M. M. nigeriana Alexander, 1974, the type species of the genus, was described from a unique male with antennae broken beyond the fifth segment, having a conspicuous long-oval pocket with abundant long setae in cell $r_{3}$ just behind $R_{2}$ [Alexander, 1974: 417], while $M$. destituta Alexander, 1976 is known only from the holotype, a female with postpedicel broken, wing lacking the setiferous pocket in cell $r_{3}$ mentioned above [Alexander, 1976: 344]. Probably the vein $R_{3}$ greatly atrophied yet present as in Medleromyia tanzanica, sp.n. constitutes an abnormal venation for $\mathrm{Me}$ dleromyia. Additionally, the striking resemblance of venation of Medleromyia tanzanica, sp.n. with that of Eupilaria nigeriana Alexander, 1972 has been noticed. E. nigeri$a n a$, the first representative of the genus in the Afrotropical region, was described from a female with legs broken beyond tibia [Alexander, 1972: 409]. It was compared with two Oriental representatives of the genus, $E$. taprobanica Alexander, 1958 and E. thysanotos Alexander, 1958, both of which also have vein $R_{3}$ atrophied and cell $d m$ open by the atrophy of cross-vein $m-m$, differing in this respect from the remaining 16 species of the genus in the Oriental region. I therefore assume that E. nigeriana may actually belong to the genus Medleromyia. A decision about the generic placement of Eupilaria nigeriana requires examination of additional material that is yet to be discovered. 


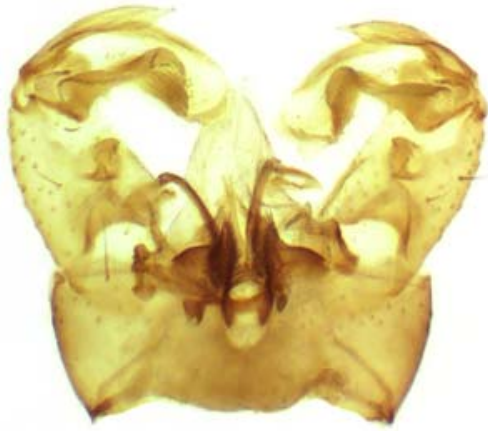

32

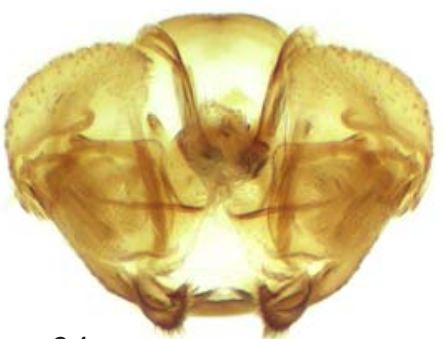

34

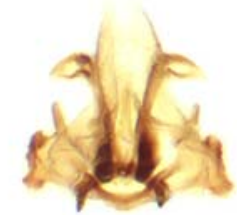

36

37
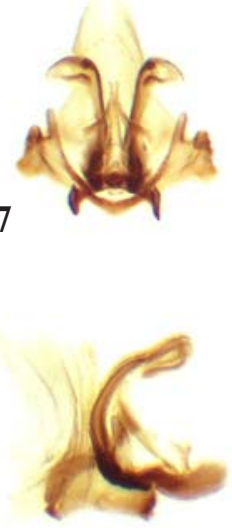

38
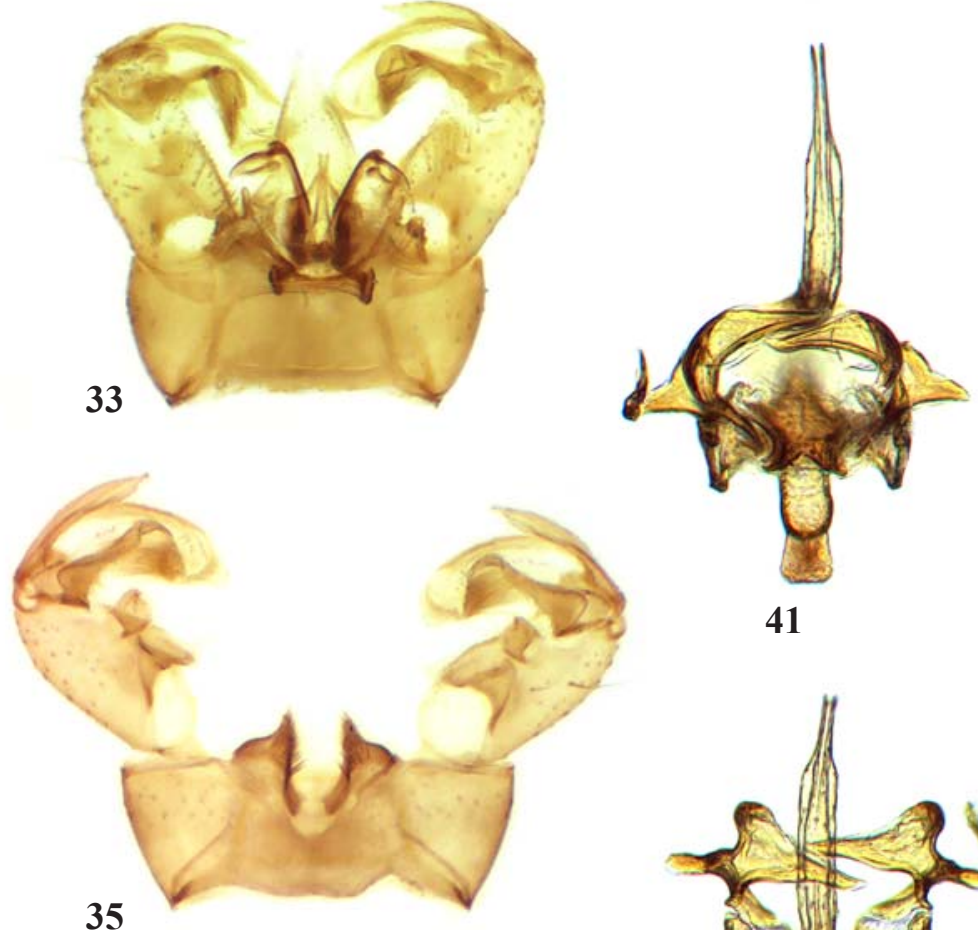

41

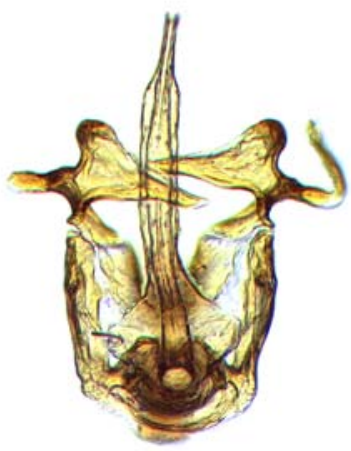

42

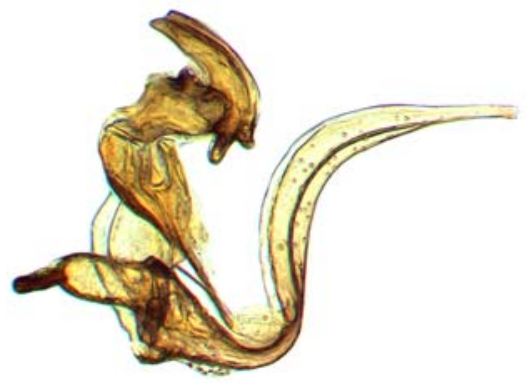

43

Figs 32-43. Medleromyia tanzanica sp.n., holotype $0^{7}: 32$ - hypopygium, dorsal view; 33 - same, ventral view; 34 - same, caudal view; 35 - same, aedeagal complex removed, dorsal view; 36 - aedeagal complex, dorsal view; 37 - same, ventral view; 38 - same, lateral view; Pilaria morogoroensis sp.n., holotype $\sigma^{7}: 39$ - hypopygium, dorsal view; 40 - same, ventral view; 41 - aedeagal complex, dorsal view; 42 - same, ventral view; 43 - same, lateral view. Not to the same scale.

Рис. 32-43. Medleromyia tanzanica sp.n., голотип О': 32 — гипопигий, вид сверху; 33 — то же, вид снизу; 34 - то же, вид сзади; 35 - то же, эдеагус удален, вид сверху; 36 - эдеагус, вид сверху; 37 - то же, вид снизу; 38 — то же, вид сбоку; Pilaria morogoroensis sp.n., голотип $\sigma^{7}: 39$ - гипопигий, вид сверху; 40 - то же, вид снизу; 41 - эдеагус, вид сверху; 42 - то же, вид снизу; 43 - то же, вид сбоку. Масштаб разный. 


\section{Pilaria morogoroensis, sp.n.}

Figs 3, 23, 39-43.

MATERIAL EXAMINED. Holotype, $0^{7}$, TANZANIA, Morogoro env., $6.85^{\circ} \mathrm{S}, 37.76^{\circ} \mathrm{E}, 2-3 . X \mathrm{XI} .2015$, N. Vikhrev leg. Paratype, + , same location and data.

DIAGNOSIS. A crane-fly of moderate size, legs mostly brown with tarsi not whitened, wings strongly suffused with brown; $R_{2}$ about its own length beyond the fork of $R_{3+4} ;$ cell $m_{1}$ one-third longer than its petiole; a few trichia on cross-veins; parameres of equal size, transverse, subtriangular, inner arms narrowed to acute tips, outer arms bent apically into short subacute crest-like appendages; penis large, strongly curved.

DESCRIPTION. Male. Measurements. Body length, 5 $\mathrm{mm}$, wing length, $5.5 \mathrm{~mm}$, hind leg, $13 \mathrm{~mm}$. Head brown above with frons yellow, yellow below, eyes large. Rostrum yellow brown, palpi brown. Antennae of moderate length, scape yellow, the remainder brown, flagellomeres elongateoval with yellowish pubescence, longest verticils on flagellomeres 4 to 6 about one-third longer than segments, the terminal flagellomere narrow, half the length of the penultimate segment, with two terminal bristles.

Thorax with general colouration yellow, pronotum brown dorsally, thoracic dorsum brown yellow, mediotergite yellow posteriorly. Legs with coxae and trochanters yellow, bases of femora indistinctly and narrowly yellow, tips of femora slightly widened, the remainder brown, hind tarsi yellowed; tibial spurs in fore legs apparently very short or absent. Halteres infuscated, basal fifths of stems yellow.

Wings (Fig. 3) strongly tinged with brown, veins brown, stigma distinct, oval. Macrotrichia on $R, R s, M, A_{1}$, and longitudinal veins beyond cord, a few trichia on cross-veins (Fig. 23 ) including $m-m$ (2-3 trichia), basal section of $C u A_{1}$ (2-3 trichia), and basal section of $M_{3}$ (a single trichia near midlength), which is rather remarkable. Venation: tip of $S c_{1}$ about the level of fork of $M$ or three-fourths the length of $R s, S c_{2}$ ends more distally, at five-sixths the length of $R s$; vein $S c_{1}$ almost transverse, very short, about half the length of $S c_{2}$; $R s$ weakly angulated near base, shorter than $R_{4}$, twice as long as $R_{2+3+4}$, cell $1 r_{1}$ narrow; $R_{2}$ oblique, its tip indistinct, about its own length beyond the fork of $R_{3+4}$, half as long as $R_{1+2} ; R_{2+3+4}$ almost in longitudinal alignment with $R s ; R_{4}$ long, strongly curved so cell $r_{2}$ more than 2 times wider than $r_{3}$; basal section of $R_{5}$ shorter than $R_{2}$, only half the length of $r-m$, almost transverse; cell $m$ one-third longer than its petiole; cell $\mathrm{dm}$ equal to the distal section of $C u A_{1}$; basal section of $C u A_{1}$ more than 1.5 its length beyond the fork of $M$, subequal to $C u A_{2} ; A_{1}$ ends roughly at the level of tip of $S c_{2}, A_{2}$ at the level of origin of $R s ; C u P$ distinct.

Abdomen with tergites brown yellow, sternites more yellowed. Hypopygium (Figs 39-40) of general structure typical for the genus; tergite 9 trapezoidal, wider posteriorly, posterior border slightly convex medially; gonocoxite elongatecylindrical, twice longer than wide, weakly curved, narrowed posteriorly; two gonostyli, terminal in position, outer gonostylus glabrous, strongly curved, heavily sclerotised, tapering to a long acute tip, inner gonosylus longer, more pale, with numerous hairs, curved in apical half, tip shorter, obtuse; aedeagal complex (Figs 41-43) with parameres of equal size, transverse, subtriangular, inner arms narrowed to acute tips, outer arms bent apically into short subacute crest-like appendages; penis large, strongly curved, dilated medially, tip narrow, bifid; vesica of moderate size, depressed oval, dorsal apodeme of vesica trapezoidal.

Female. Measurements. body length, $5.5 \mathrm{~mm}$, wing length, $6 \mathrm{~mm}$, hind leg, $15 \mathrm{~mm}$. Generally similar to male, ovipositor yellow brown, cerci long, gently curved, hypovalvae shorter.
DISTRIBUTION. Tanzania.

ETYMOLOGY. The new species is named after Morogoro, a city in eastern Tanzania (Morogoro Region) in which environs it was collected.

DISCUSSION. P. morogoroensis sp.n. differs from two known regional species with dark tarsi in details of venation as well as in structure of antennae and male hypopygium (Pilaria sordidipes Alexander, 1972, Nigeria, female: thoracic dorsum mostly dark brown, cell $m$, shorter than its petiole, etc. [Alexander, 1972]; Pilaria perelongata Alexander, 1976, Nigeria, male: antennae very long with abundant erect setae, $R_{2+3}$ shorter than $R_{2}$, parameres of different structure and apparently of unequal size, etc. [Alexander, 1976]).

\section{Subfamily Limoniinae}

\section{Elephantomyia (Elephantomyia) catarractes, sp.n.} Figs 4, 44-49.

MATERIAL EXAMINED. Holotype, $0^{\top}$, TANZANIA, Morogoro env., Uluguru Mts, Majiyanakwendo waterfall, $6.87717^{\circ} \mathrm{S}$, $37.68242^{\circ} \mathrm{E}, 1081 \mathrm{~m}$ a.s.1., 20.IX.2012, D. Gavryushin leg. Paratypes, $2 \sigma^{7} \sigma^{7}$, same location and data.

DIAGNOSIS. A crane-fly with prescutum striped with brown, pleurae variegated with brown, legs mostly brown, tips of femora distinctly yellow, wings conspicuously patterned with brown; basal section of $R_{4+5}$ very short or absent; cell $d m$ subequal to the distal section of $M_{3}$; penis coiled, with a stout spine beyond midlength.

DESCRIPTION. Male. Measurements. Body length, 4.5$6.5 \mathrm{~mm}$, wing length, $5.8-7 \mathrm{~mm}$, rostrum, 3.8-5 mm. Head brown, with yellow grey pruinosity. Antennae dark brown. Rostrum dark brown, palpi apparently 3-segmented.

Thorax with cervical sclerites reddish yellow. Antepronotum yellow with brown dorsal stripe, postpronotum brown. Prescutum yellow, more reddish yellow on the interspaces, with four brown stripes, the median pair almost completely confluent, divided by a capillary yellow line, lateral stripes shorter, narrowed anteriorly, continued to scutal lobes which are mostly brown except triangular yellow areas on posterior border opposite bases of wings. Scutellum and mediotergite brown. Pleurae yellow, extensively patterned with brown, wide oblique stripe from base of fore coxa across anterior spiracle to base of wing, second brown stripe from katepisternum across anepimeron to laterotergite. Halteres uniformly yellow. Legs brown, in paratypes mid and hind coxae yellowed, tips of femora narrowly (about one-twelfth their length) yellow, tips of tibiae very narrowly yet distinctly yellowed, tarsi appear brownish yellow. Legs with semi-appressed hairs.

Wings (Fig. 4) comparatively wide, tinged with brownish, with a distinct brown pattern consisting of a spot in arcular area, a larger spot at origin of $R s$, a still larger stigmal spot which is connected with a seam on cord, and a seam on outer edge of cell $d m$ ( $m-m$ and basal section of $\left.M_{3}\right)$. Veins $C u A$ and $A_{2}$ narrowly seamed with brown. Outer regions of cells $r_{1}$ to $r_{5}$ near wing margin narrowly yellowish, outer regions of cells $m_{2}$ to $a_{2}$ near wing margin narrowly brownish grey. Venation: $S c_{1}$ at midlength of $R s$, in cases rather faint, $S c_{2}$ close to it; $R S$ strongly arcuated at onefourth its length, shorter than $R_{3}$, in longitudinal alignment with $R_{4+5} ; R_{1}$ and $R_{3}$ curved upwards, $R_{4+5}$ straight, cell $r_{1} 1.5$ times wider than $r_{3}, r_{3}$ twice as wide as $r_{5} ; r-m$ nearly transverse, either at the fork of $R s$ or about one-half its length beyond the fork so a very short basal section of $\mathrm{R}_{4+5}$ is preserved; cell $d m$ pentagonal, large, 2 times longer than the distal section of $C u A_{1}$, subequal to the distal section of $M_{3}, 1.5$ times shorter than $M_{1+2}$; basal section of $C u A_{1}$ at or shortly beyond the fork of $M, 1.5$ times shorter than distal 

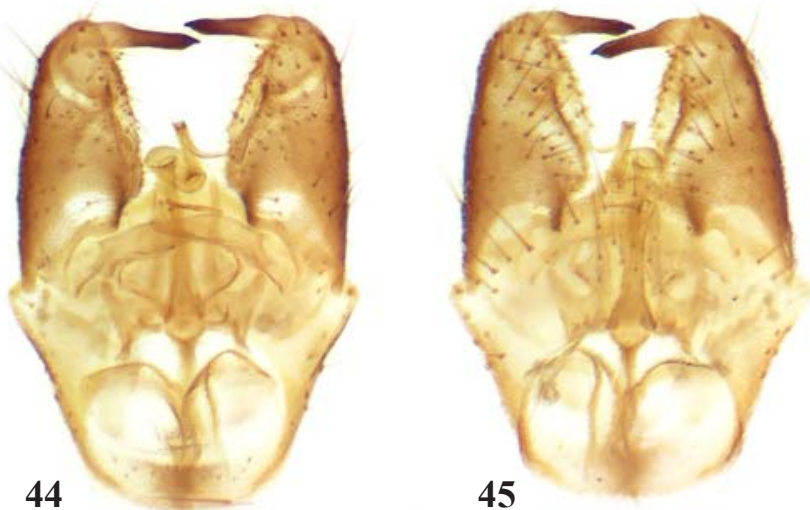

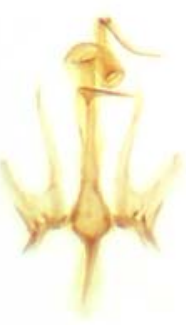

48

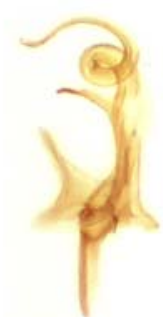

49

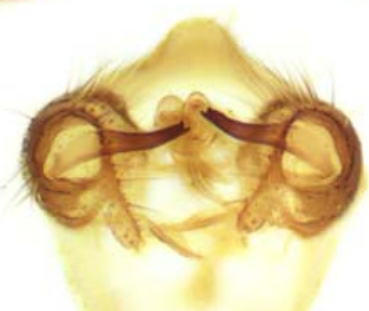

46
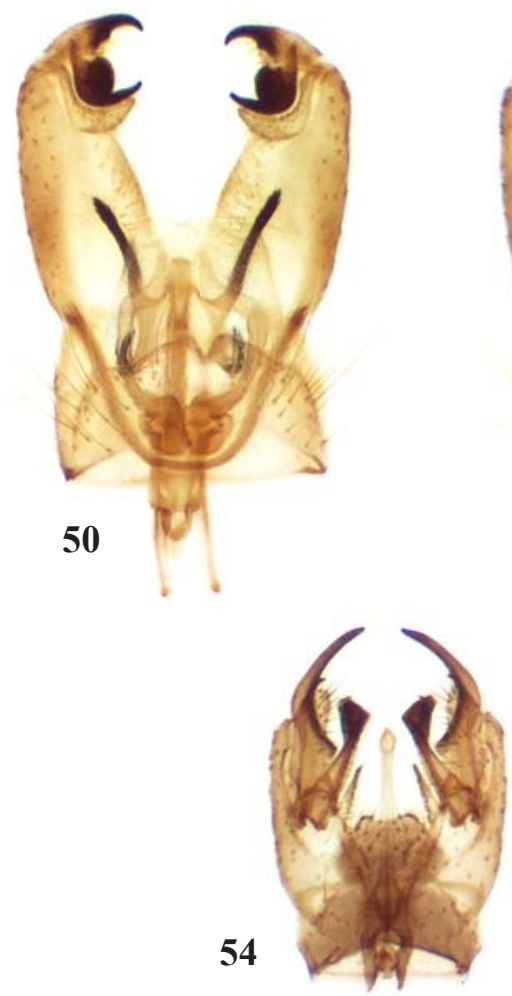

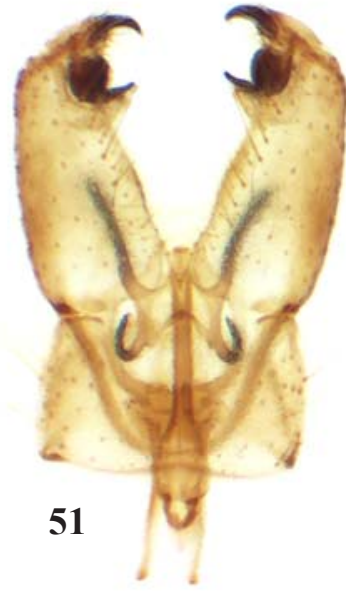

47

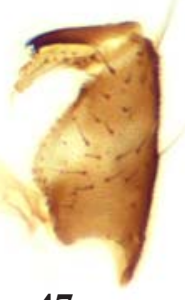

52
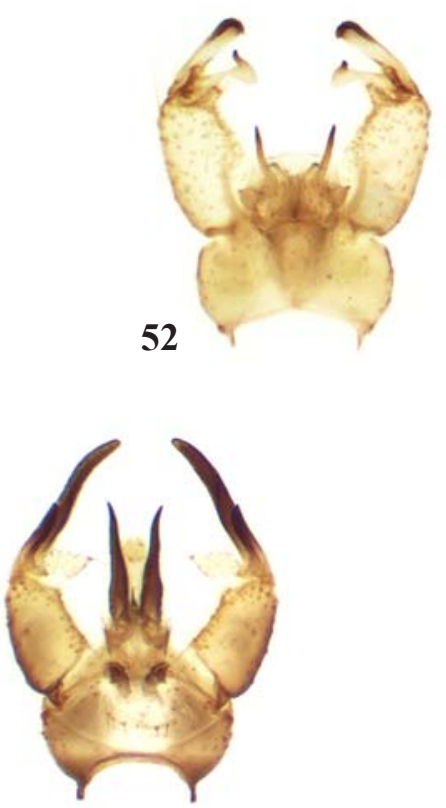

53
55

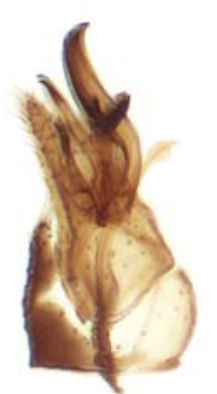

56

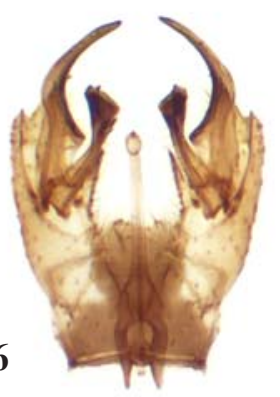

Figs 44-56. Elephantomyia (Elephantomyia) catarractes sp.n., holotype $\mathrm{O}^{\top}: 44$ - hypopygium, dorsal view; 45 - same, ventral view; 46 - same, caudal view; 47 - gonopod, ventral view; 48 - aedeagal complex, dorsal view; 49 - same, lateral view; Erioptera (Erioptera) subirrorata, $O^{7}: 50$ - hypopygium, dorsal view; 51 - same, ventral view; Erioptera (Meterioptera) persinuata, $\bigcirc^{7}: 52$ - hypopygium, dorsal view; Gonomyia (Leiponeura) apiculata, $\mathrm{O}^{3}: 53$ - hypopygium, dorsal view; Idiocera (Idiocera) spuria, $\bigcirc^{7}: 54$ — hypopygium, dorsal view; 55 - same, lateral view; 56 - same, ventral view. Not to the same scale.

Рис. 44-56. Elephantomyia (Elephantomyia) catarractes sp.n., голотип О': 44 - гипопигий, вид сверху; 45 - то же, вид снизу; 46 - то же, вид сзади; 47 - гоноподит, вид снизу; 48 - эдеагус, вид сверху; 49 - то же, вид сбоку; Erioptera (Erioptera) subirrorata, $\mathrm{O}^{7}: 50$ - гипопигий, вид сверху; 51 - то же, вид снизу; Erioptera (Meterioptera) persinuata, О': 52 - гипопигий, вид сверху; Gonomyia (Leiponeura) apiculata, $\bigcirc^{\top}: 53$ - гипопигий, вид сверху; Idiocera (Idiocera) spuria, $0^{\top}: 54$ — гипопигий, вид сверху; 55 то же, вид сбоку; 56 - то же, вид снизу. Масштаб разный. 
section of $C u A_{2} ; A_{1}$ ends just before the level of fork of $R s$, nearly straight, $A_{2}$ far before origin of $R s$, weakly arched. Macrotrichia on $R$ and longitudinal veins approx. beyond the level of origin of $R s, A_{1}$ and $A_{2}$ glabrous.

Abdomen bicolourous, segments brown with posterior borders widely yellow. Hypopygium (Figs 44-47) with sclerites of segment 9 fused into a ring with a deep medial emargination; well-developed proctiger with a deep medial fold is located in this emargination; gonocoxite conical, almost twice longer than its maximum width, interbase present (Fig. 47), a subrectangular plate tapering to a subacute tip, interbases overlapping each other medially; two gonostyli, terminal in position, subequal in length, outer gonosylus weakly curved, heavily pigmented, apex bicuspidate, inner gonosylus pale, more curved, with numerous setae, tip truncate; aedeagal complex (Figs 48-49) with inner arms of parameres long, slender, gently curved, with acute tips, outer arms much shorter, subtriangular; penis large, tubular, of complex structure, beyond midlength with a stout spine perpendicular to its axis, apical half bent into a spiral coil with a single loop and produced beyond it into a long acute tip which is strongly curved laterad; vesica suboval, of moderate size, dorsal apodeme of vesica very large.

Female unknown.

DISTRIBUTION. Tanzania.

ETYMOLOGY. The species name (n., masc. sing.) is a

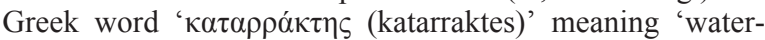
fall'.

DISCUSSION. Elephantomyia (Elephantomyia) catarractes, sp.n. is readily told from all known regional representatives of the genus by the colour pattern of legs which are mostly brown with tips of femora conspicuously yellow.

\section{New records}

\section{Subfamily Chioneinae}

\section{Ellipteroides (Ellipteroides) difficilis \\ (Alexander, 1920), comb.n.}

Figs 5, 18-21.

Limnophila (Limnophila) difficilis Alexander, 1920: 357 (description), Alexander, 1956: 280 (key), Fig. 99 (wing).

MATERIAL EXAMINED. $1 \sigma^{7}$, TANZANIA, Morogoro env., Uluguru Mts, $6.84593^{\circ} \mathrm{S}, 37.692^{\circ} \mathrm{E}, 853 \mathrm{~m}$ a.s.1., 17.IX.2012, D Gavryushin leg.; $1 \mathrm{O}^{7}, 1$ \%, TANZANIA, Morogoro env., $6.85^{\circ} \mathrm{S}$, $37.76^{\circ} \mathrm{E}, 2-3 . X \mathrm{XI} .2015$, N. Vikhrev leg.

Limnophila (Limnophila) difficilis Alexander, 1920 was described from a single female with legs except coxae and trochanters and most part of ovipositor broken [Alexander, 1920]. With fresh specimens of both sexes now available for examination, it is evident that both generic and subfamilial placement of this fly is incorrect; based on the combination of characters including details of venation, structure of male and female terminalia, and absence of tibial spurs, this species should be assigned to the nominative subgenus of Ellipteroides Becker, 1907. The male is described below.

DESCRIPTION. Male. Measurements. Body length, 7 $\mathrm{mm}$, wing length, $6.2 \mathrm{~mm}$, antenna, $3.2 \mathrm{~mm}$. Head black with abundant bluish grey pruinosity which is absent on posterior vertex (probably worn off), frons yellowish above bases of antennae. Rostrum brownish yellow, palpi with the first segment partially yellow, the remainder brown. Antennae moderately long, with scape and pedicel yellow, the former twice as big as the latter; flagellomeres with the base of the first segment yellow, the remainder brown; $1^{\text {st }}$ flagellomere elongate-oval, the remaining segments elongatecylindrical, at midlength of antenna about 6 times longer than wide, longest verticils one-third longer than segments.

Thorax with pronotum well-developed, yellow with dorsal darkening. Prescutum reddish yellow with 4 brown stripes, the intermediate pair distinct, divided by a pale line which is subequal to stripes in width posteriorly; lateral stripes shorter, faint anteriorly. Scutum and scutellum yellow, scutal lobes with triangular brown spots. Mediotergite yellow brown anteriorly, brown posteriorly, with an indistinct yellow median line. Pleurae yellow, dorsopleural membrane narrowly darkened at midlength. Halteres infuscated with basal half of stem yellow. Legs yellow, tips of femora indistinctly darkened.

Wings (Fig. 5) with a yellowish brown tinge, stigma very faint; veins $C$ and $S c$ yellow brown, the remaining veins brown, prearcular field yellowish. Venation: anterior arculus present, $S c_{1}$ ending at the level of fork of $R s$ or just shortly beyond it, $S c_{2}$ at about three-fourths $R s, S c_{1}$ alone subequal to $R_{1+2}$; origin of $R s$ at about 0.4 length of wing, $R s$ long, gently arcuated, subequal to $R_{3}$, almost 3 times longer than $R_{2+3+4}$; $R_{1+2}$ twice as long as $R_{2}, R_{2}$ on $R_{3}$, shortly beyond the fork of $R_{3+4}^{1+2} ; R_{2+3+4}$ oblique, twice as long as the basal section of $R_{5} ; R_{4}$ curved downwards so cell $r_{3}$ around 3 times as wide as $r_{4}$ and $r_{5} ; r-m$ longer than the basal section of $R_{5}$, nearly in oblique alignment with $R_{2}$; cell $d m$ open by the atrophy of basal section of $M_{3}$, cell $m_{2}$ more than a half longer its petiole; basal section of $\mathrm{CuA}$ about one-third its length beyond the fork of $M, 1.5$ times as long as the basal section of $R_{5}$, half the length of $C u A_{2} ; A_{1}$ ending at the level of fork of $R s$, almost straight, $A_{2}$ at origin of $R s$, weakly curved caudad distally. Macrotrichia on $R s$ and longitudinal veins approx. beyond the level of origin of Rs excluding $M$ and $C u A_{2}$.

Abdomen with tergites yellow brown, sternites clearer yellow; sternite 8 (Fig. 22) very large, curved, about 6 times as long as tergite 8 , with very wide subtriangular emargination anteriorly so nearly bilobed. Male hypopygium (Figs 18-21) apparently retracted into abdominal segment 8 , tergite 9 transverse with deep subrectangular emargination posteriorly; gonocoxite with usual apical lobe, dorsomesal edge strongly pigmented with large subtriangular lobe above midlength, ventromesal area with abundant long hairs; apparently two gonostyli, both not projecting beyond tips of apical lobes of gonocoxites, outer gonostylus small, produced apically into slender rod with obtuse tip, inner gonostylus much larger, sclerotized, T-shaped, base stout, strongly curved, bifurcate at apex with inner arm wide, subtriangular, outer arm longer, more slender, tip subacute, mesal surfaces of both arms with a few short spines; aedeagus large, subequal in length to gonocoxite, curved and narrowed apically into obtuse tip, dorsal surface with long hairs near midlength.

The single available female differs from male mostly in shorter antennae, details of colouration (mostly brown, including pronotum and anterior pleurae, prescutal stripes almost confluent, spots on scutal lobes more distinctly being a continuation of lateral prescutal stripes, fore coxae brown) and venation of wings which are more strongly tinged with brown ( $R_{2}$ at the fork of $R_{3+4}$, cell $m_{2}$ more than twice its petiole, $\mathrm{CuA}$ almost 3 times longer than basal section of $\left.C u A_{1}\right)$. These differences, although substantial, still may represent a case of sexual dimorphism and/or intraspecific variation; so the exact systematic position of the female remains uncertain but it's undoubtedly an Ellipteroides (Ellipteroides) sp.

DISTRIBUTION. Malawi, Tanzania (first record). 


\section{Erioptera (Erioptera) subirrorata Alexander, 1920} Figs 6, 50-51.

MATERIAL EXAMINED. $2 \sigma^{\top} \sigma^{7}, 1$, TANZANIA, $40 \mathrm{~km}$ SE of Njombe, $9.52^{\circ} \mathrm{S}, 35.09^{\circ} \mathrm{E}, 1700 \mathrm{~m}$ a.s.l., 17.XII.2015, N. Vikhrev leg.

Easily distinguished from the regional species of Erioptera (s.str.) by details of male hypopygium (Figs 50-51), wings with cells glabrous and veins beyond cord with abundant small brown clouds and spots, much like in Conosia spp. (Fig. 6).

DISTRIBUTION. Ethiopia, Kenya, Nigeria, South Africa, Zimbabwe, Tanzania (first record).

Erioptera (Meterioptera) persinuata Alexander, 1964 Fig. 52.

MATERIAL EXAMINED. $1 \mathrm{O}^{7}$, TANZANIA, Nyasa Lake, Matema, $9.5^{\circ} \mathrm{S}, 34.01^{\circ} \mathrm{E}, 15 . \mathrm{XII} .2015$, N. Vikhrev leg.

Differs from the regional members of the subgenus in details of male hypopygium (Fig. 52) and vein $A_{2}$ strongly sinuous, much like in the nominative subgenus.

DISTRIBUTION. Lesotho, Tanzania (first record)

Gonomyia (Leiponeura) apiculata Alexander, 1960 Fig. 53.

MATERIAL EXAMINED. $5 \sigma^{7} \sigma^{7}, 1$ \%, TANZANIA, Bagamoyo env., $6.46112^{\circ} \mathrm{S}, 38.91915^{\circ} \mathrm{E}, 17 \mathrm{~m}$ a.s.1., $12 . \mathrm{IX} .2012 ; 8 \mathrm{O}^{7} \mathrm{O}^{7}$, 2 Oㅇ, TANZANIA, Bagamoyo env., Ruvu river, $6.47965^{\circ} \mathrm{S}$, $38.8293^{\circ} \mathrm{E}, 4 \mathrm{~m}$ a.s.1., 13.IX.2012, all D. Gavryushin leg.

Readily told from other regional species in the structure of male hypopygium (Fig. 53).

DISTRIBUTION. Mozambique, Tanzania (first record).

Idiocera (Idiocera) spuria (Bergroth, 1888) Figs 54-56.

MATERIAL EXAMINED. $10^{\top}$, TANZANIA, Bagamoyo env., $6.46112^{\circ} \mathrm{S}, 38.91915^{\circ} \mathrm{E}, 17 \mathrm{~m}$ a.s.1., 12.IX.2012, D. Gavryushin leg.

Differs from the regional species with unpatterned wings, short $S c, R_{1+2}$ and $R_{3}$ approximated at wing margin in the structure of male hypopygium (Figs 54-56).

DISTRIBUTION. Widespread in the Afrotropical region, incl. Cape Verde Is, Mozambique, Senegal, South Africa, Zimbabwe, Tanzania (first record).

Styringomyia leucopeza Edwards, 1914

MATERIAL EXAMINED. 1 o , TANZANIA, Bagamoyo env., $6.46112^{\circ} \mathrm{S}, 38.91915^{\circ} \mathrm{E}, 17 \mathrm{~m}$ a.s.1., 11.IX.2012, D. Gavryushin leg.; 1 ㅇ, TANZANIA, Morogoro env., Uluguru Mts, $6.84593^{\circ} \mathrm{S}$, $37.692^{\circ} \mathrm{E}, 853 \mathrm{~m}$ a.s.1., 17.IX.2012, D. Gavryushin leg.; $1 \mathrm{O}^{\mathrm{T}}$, TANZANIA, Morogoro env., $6.85^{\circ} \mathrm{S}, 37.76^{\circ} \mathrm{E}, 2-3 . X I I .2015$, N. Vikhrev leg.

Readily told from the numerous regional representatives of the genus by black colouration except for hind tarsi and sternite 9 deeply forked at apex.

DISTRIBUTION. Malawi, Mozambique, South Africa, Uganda, Zimbabwe, Tanzania (first record).

\section{Styringomyia vittata Edwards, 1914 Figs 57-60.}

MATERIAL EXAMINED: $7 \bigcirc^{7} \sigma^{7}, 11$ ㅇ (in alcohol), TANZANIA, Nyasa Lake, Matema, $9.5^{\circ} \mathrm{S}, 34.01^{\circ} \mathrm{E}$, 15.XII.2015, N. Vikhrev leg.

Differs from the related species in the structure of male (Figs 57-58) and female (Figs 59-60) terminalia as well as by details of colouration, especially median dark stripe on abdomen dorsally in both sexes.

DISTRIBUTION. Widespread in the Afrotropical region, incl. Democratic Republic of the Congo, Ghana, Kenya, Liberia, Malawi, Mozambique, Nigeria, South Africa, Zimbabwe, Tanzania (first record).

\section{Subfamily Limnophilinae \\ Pseudolimnophila (Pseudolimnophila) frugi \\ (Bergroth, 1888)}

MATERIAL EXAMINED. 1 , TANZANIA, Tunduru env., $10.99^{\circ} \mathrm{S}, 37.29^{\circ} \mathrm{E}, 540 \mathrm{~m}$ a.s.1., 19.XII.2015, N. Vikhrev leg.

Females can be distinguished from the numerous regional members of the genus by details of colouration and venation.

DISTRIBUTION. Widespread in eastern and southern Africa, incl. Mozambique, Namibia, South Africa, Tanzania (first record).

\section{Subfamily Limoniinae}

Geranomyia euryphallus (Alexander, 1960)

MATERIAL EXAMINED. 1 , TANZANIA, Morogoro env., Uluguru Mts, Majiyanakwendo waterfall, $6.87717^{\circ} \mathrm{S}, 37.68242^{\circ} \mathrm{E}$, $1081 \mathrm{~m}$ a.s.1., 21.IX.2012; 1 , TANZANIA, Morogoro, Ngerengere river, $6.83862^{\circ} \mathrm{S}, 37.66855^{\circ} \mathrm{E}, 513 \mathrm{~m}$ a.s.1., 22.IX.2012, all D. Gavryushin leg.

Readily told from females of the related species with unpatterned wings, $S c$ at or beyond midlength of $R s$, prescutum without stripes, and large cell $d m$, by bicolourous rostrum.

DISTRIBUTION. Mozambique, Tanzania (first record).

Geranomyia errana (Alexander, 1930)

MATERIAL EXAMINED. 1 , TANZANIA, Morogoro env., $6.85^{\circ} \mathrm{S}, 37.76^{\circ} \mathrm{E}, 2-3 . \mathrm{XII} .2015$, N. Vikhrev leg.

Distinguished from females of the regional species with extensive but non-ocellate wing pattern, costal interspaces with pale interpolated darkenings, $S c$ at the fork of $R s$, no spot at end of $A_{2}$, and large cell $d m$ (e.g. G. ornatrix Alexander, 1926) by details of venation and wing pattern.

DISTRIBUTION. Democratic Republic of the Congo, Mozambique, Tanzania (first record).

Helius (Helius) brevisector Alexander, 1956

MATERIAL EXAMINED. $10^{\top}$, TANZANIA, $15 \mathrm{~km} \mathrm{~N}$ of Njombe, $9.204^{\circ} \mathrm{S}, 34.784^{\circ} \mathrm{E}, 1850 \mathrm{~m}$ a.s.1., 16.XII.2015, N. Vikhrev leg.

Easily distinguished from the regional members of the genus by the details of venation (basal section of $R_{4+5}$ very long, half the length of $R s$ or more).

DISTRIBUTION. Democratic Republic of the Congo, Ethiopia, Kenya, Uganda, Zimbabwe, Tanzania (first record).

Orimarga (Orimarga) mashonensis Alexander, 1959 Figs 67-74.

MATERIAL EXAMINED. $1 \sigma^{7}, 2$ 오, TANZANIA, Songea env., $10.63^{\circ} \mathrm{S}, 35.66^{\circ} \mathrm{E}, 1100 \mathrm{~m}$ a.s.1., $17 . X I I .2015$, N. Vikhrev leg.

The male of this species is recorded for the first time and described below.

DESCRIPTION. Male. Measurements. Body length, $6.5 \mathrm{~mm}$, wing length, $6 \mathrm{~mm}$. Head brown, grey pruinose, with long mostly proclinate yellowish hairs. Eyes large, shortly holoptic below. Frons less than twice the width of scape. Rostrum orange yellow, elongate, about three-fourths the length of head. Palpi brownish black. Antennae with scape yellow, 2.5 times as long as pedicel, pedicel and flagellomeres dark brown; flagellomeres short-oval, with abundant greyish yellow pubescence, verticils a little shorter than segments.

Thorax: cervical sclerites and pronotum yellow with brown dorsal areas. Thoracic dorsum brown with yellowish grey pruinosity, prescutum without any traces of stripes. Pleurae brownish yellow, at certain angles appearing lighter yellow because of yellowish grey pruinosity, patterned with brown, including laterotergite and triangular spot on upper anepisternum. Halteres yellow with knobs infuscated. Legs 
with anterior surfaces of fore coxae brown, the remaining coxae and trochanters yellow, bases of femora narrowly and indistinctly yellow, the remainder of legs brown yellow, tips of tarsi darkened; legs relatively long, tibiae longer than femora and one-third longer than tarsi, basitarsi more than twice as long as the remaining tarsomeres.

Wings narrow, weakly iridescent, slightly tinged with greyish yellow, stigma absent, veins $C$ and $S c$ yellow brown,

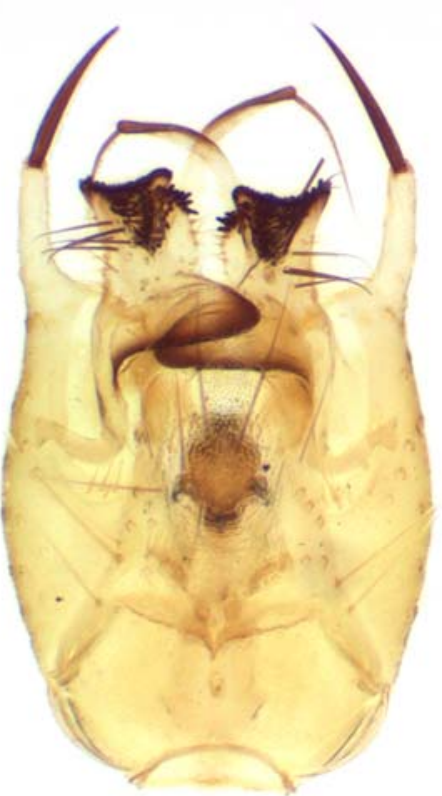

57

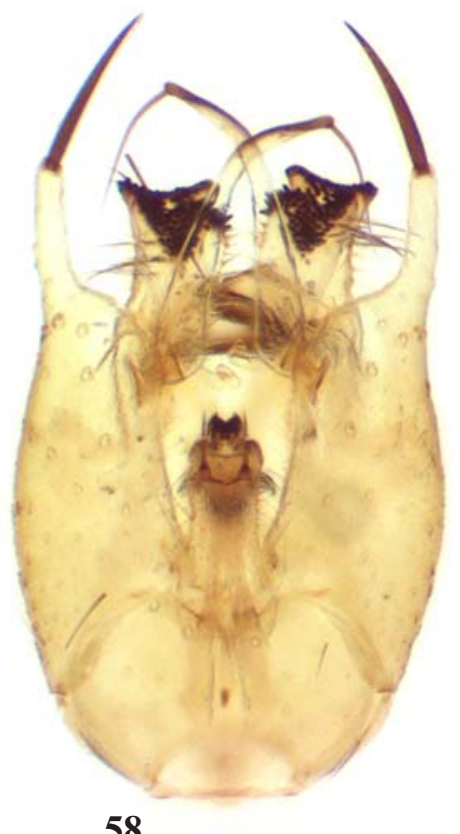

58
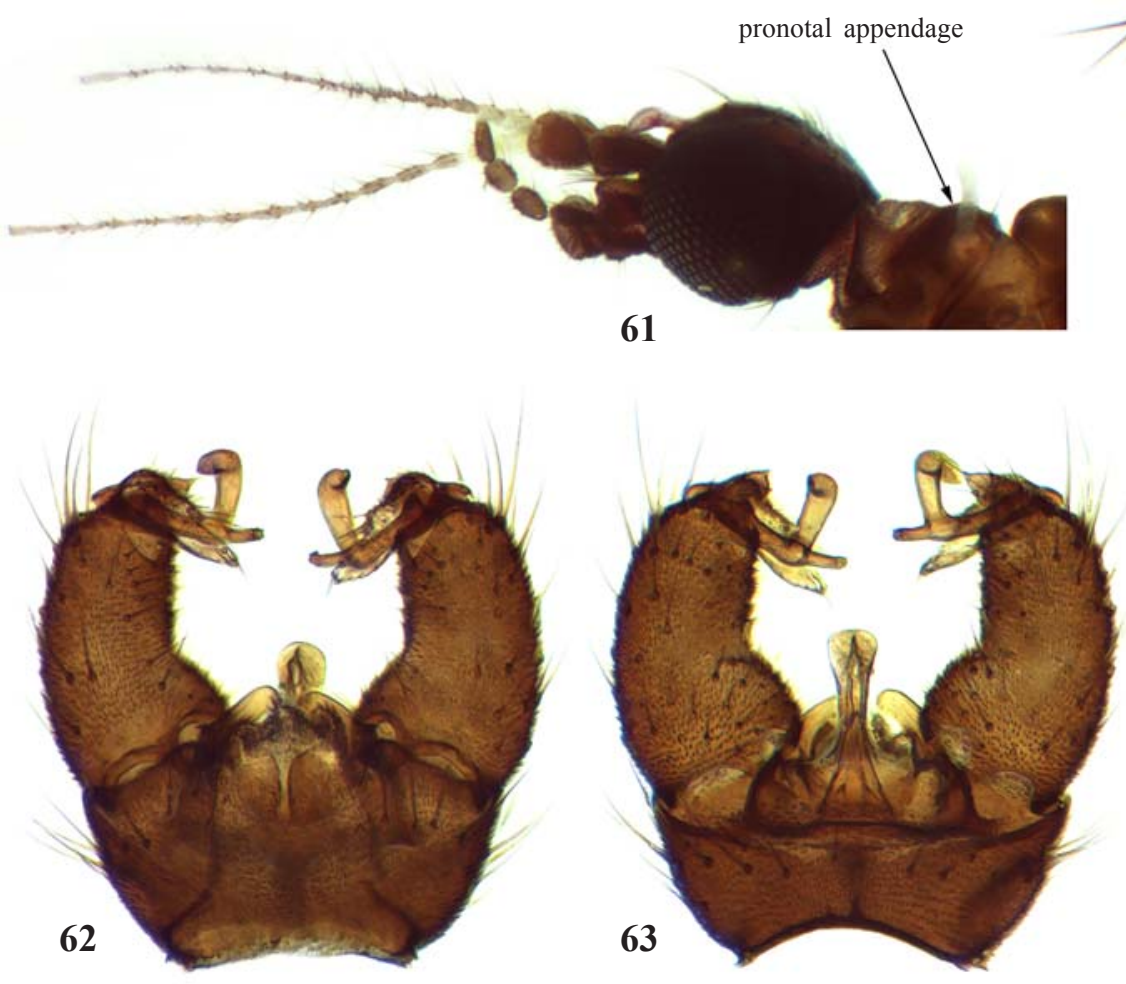

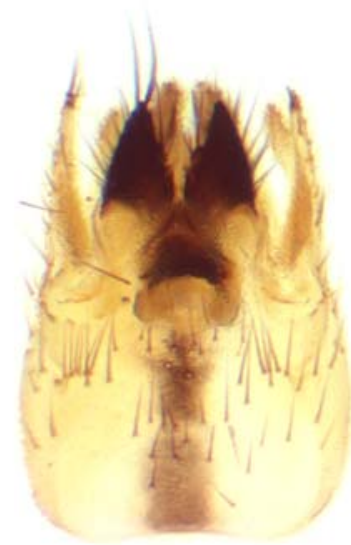

59

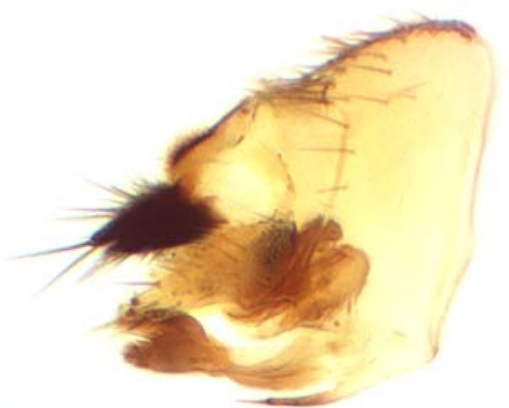

60
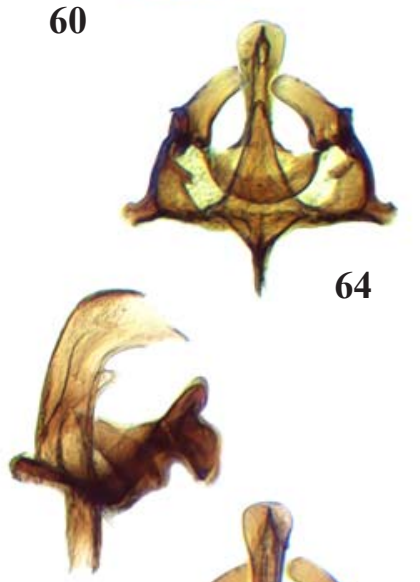

65

Figs 57-66. Styringomyia vittata, $\bigcirc^{\top}: 57$ - hypopygium, sternal view; 58 - same, tergal view; Styringomyia vittata,, : 59 — ovipositor, dorsal view; 60 - same, lateral view; Trichoneura (Ceratolimnobia) munroi, $\sigma^{7}: 61$ - head and pronotal appendages; 62 - hypopygium, dorsal view; 63 - same, ventral view; 64 - aedeagal complex, dorsal view; 65 - same, lateral view; 66 - same, ventral view. Not to the same scale.

Рис. 57-66. Styringomyia vittata, oт: 57 - гипопигий, вид сверху; 58 - то же, вид снизу; Styringomyia vittata, вид сверху; 60 - то же, вид сбоку; Trichoneura (Ceratolimnobia) munroi, ơ': 61 — голова и выросты переднеспинки; 62 - гипопигий, вид сверху; 63 - то же, вид снизу; 64 - эдеагус, вид сверху; 65 - то же, вид сбоку; 66 - то же, вид снизу. Масштаб разный. 
the remaining veins brown. Venation: $S c_{1}$ ending at threefourths $R s, S c_{2}$ near its tip, faint; $R s$ gently arcuated, longer than $R_{2+3}$, twice as long as the basal section of $R_{4+5} ; R_{1+2}$ very long, 2.5 times as long as $R_{2} ; R_{3}$ and $R_{4+5}$ downcurved at wing margin so cell $r_{5}$ very narrow; the basal section of $R_{4+5}$ weakly angulated at one-fourth its length; $r-m$ two-thirds $R_{2}$, subequal to the basal section of $M_{1+2} ; M_{1+2}$ almost straight; cell $d m$ open by the atrophy of $m-m ; M_{3} 1.5$ times longer than the distal section of $C u A_{1}$; cell $m_{2}$ longer than its petiole; basal section of $C u A_{1}$ oblique, at the level of midlength of $R s ; A$ ending at midlength of the basal section of $R_{4+5}, A_{2}$ far before the origin of $R s$, its proximal half strongly sinuous. Macrotrichia on $R, R s$ and longitudinal veins beyond cord from $R_{1+2}$ to $C u A_{1}$, inclusive, about 7 trichia on $C u A$ before its fork.

Abdomen with tergites yellow brown, sternites clearer yellow. Posterior three-fourths of segment 6 with conspicuous fringe of long yellowish hairs laterally (Fig. 74), length of hairs about two-thirds the length of the segment. Hypopygium (Figs 67-73) large, orange yellow, tergite 9 greatly reduced, flanked laterally by sternite 9 which is bent on the dorsal surface of hypopygium, edges of flanks with long hairs; sternite 9 (Fig. 73) pentagonal, narrowed posteriorly,

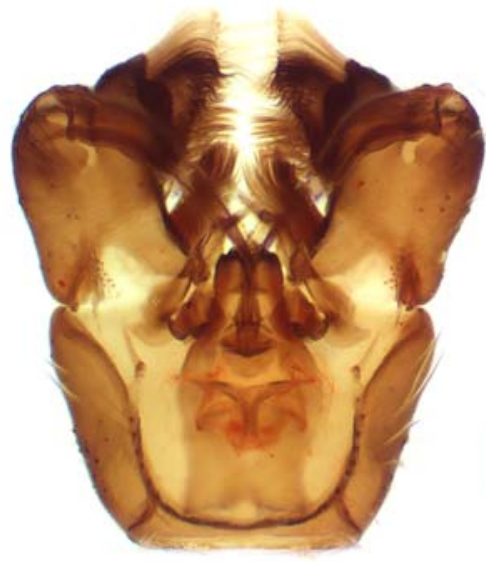

67

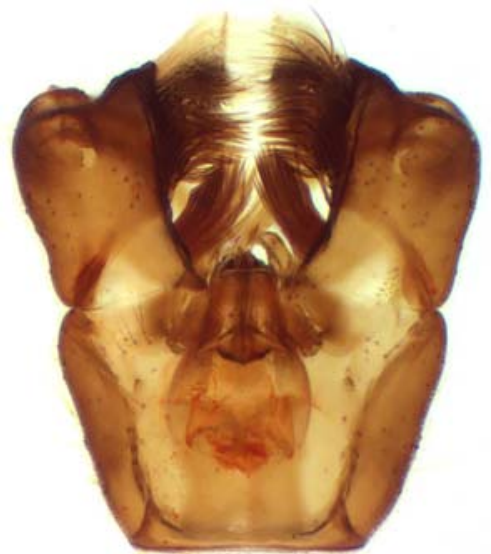

69

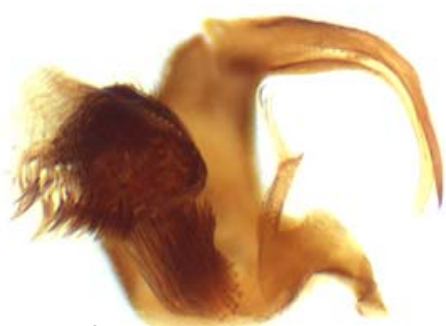

72

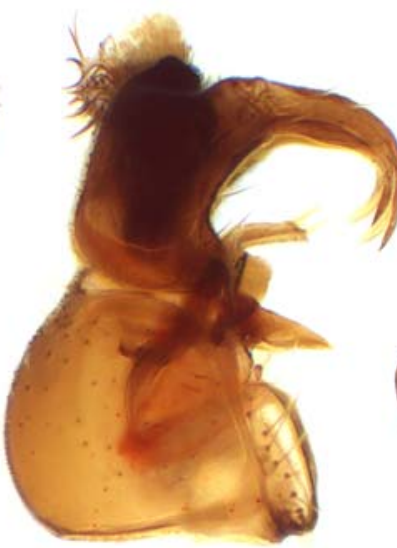

68

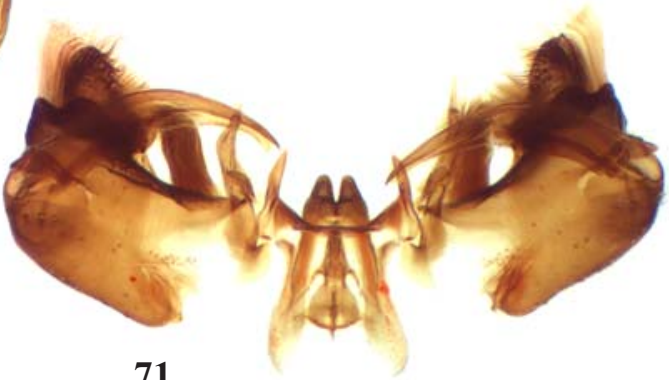

71

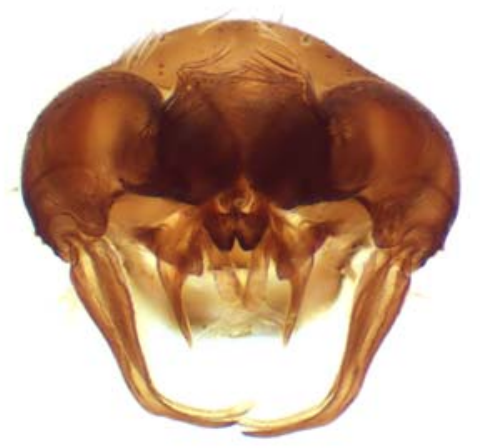

70

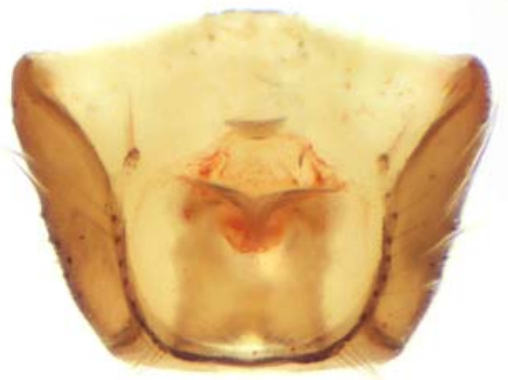

73

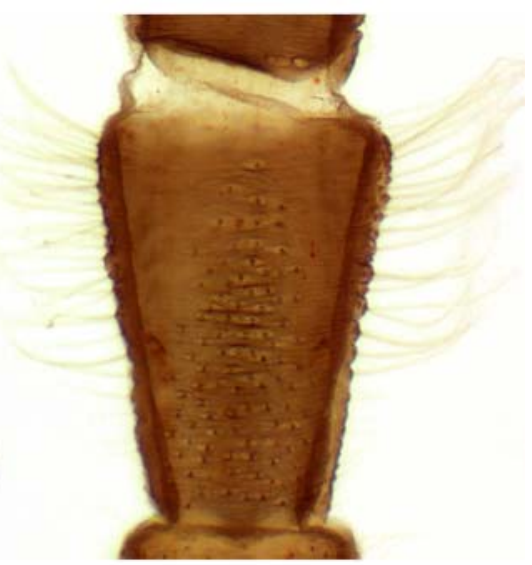

74

Figs 67-74. Orimarga (Orimarga) mashonensis, $0^{7}$ : 67 - hypopygium, dorsal view; 68 - same, lateral view; 69 - same, ventral view; 70 - same, caudal view; 71 - same, segment 9 removed, dorsal view; 72 - gonopod, view from inner side; 73 - abdominal segment 9 , dorsal view; 74 - abdominal segment 6, dorsal view. Not to the same scale.

Рис. 67-74. Orimarga (Orimarga) mashonensis, О': 67 - гипопигий, вид сверху; 68 - то же, вид сбоку; 69 - то же, вид снизу; 70 — то же, вид сзади; 71 — то же, сегмент 9 удален, вид сверху; 72 — гоноподит, вид изнутри; 73 —-й сегмент брюшка, вид сверху; 74 -6-й сегмент брюшка, вид сверху. Масштаб разный. 
its surface strongly convex, dorsomesal surface of sternite 9 in upper half with conspicuous setiferous tubercle bearing 5 setae; gonocoxite cylindrical, with large ventomesal lobe covered with dense, curved hairs forming an extensive comblike structure, these hairs brown, continued on mesal surface of the lobe, less dense and yellow on outer surface of the lobe, mesal surface of gonocoxite at its base with a large area densely covered with even longer and more erect hairs; interbase (Fig. 72) wide basally, posterodorsal corner widely rounded, posteroventral corner produced into long subrectangular appendage, its tip truncate, with 3 very long setae which are curved apically; two gonostyli, subterminal in position, both very long, stout and strongly curved in apical half (best seen in caudal view, Fig. 70), outer gonostylus more sclerotised, tip acute, inner gonostylus a little longer, tip obtuse; aedeagal complex (Fig. 71) large, subequal in length to gonocoxite, of complex structure, parameres with inner arms fused forming a heavily pigmented plate with bilobed posterior border above penis, outer arms less pigmented, triangular, narrowed to acute tips, the bases also fused medially into a narrow bridge, penis short, straight, tip deeply bifid, vesica large, lateral apodemes of vesica welldeveloped, produced into wide lobes.

DISCUSSION. Orimarga (Orimarga) mashonensis is one the two regional species of the genus with very long vein $R_{1+2}$; the vestiture of abdominal segment 6 and details of male hypopygium described above are very distinct; the second species is Orimarga (Orimarga) fryeri Edwards, 1912 (Seychelles).

DISTRIBUTION. Zimbabwe, Tanzania (first record).

\section{Trichoneura (Ceratolimnobia) munroi}

(Alexander, 1920)

Figs 7, 61-66.

MATERIAL EXAMINED. 2 OQ, TANZANIA, Morogoro, Ngerengere river, $6.83093^{\circ} \mathrm{S}, 37.66622^{\circ} \mathrm{E}, 506 \mathrm{~m}$ a.s.1., 19.IX.2012 $2 \sigma^{\top} \sigma^{\top}, 1$ 을, TANZANIA, Morogoro, Ngerengere river, $6.83862^{\circ} \mathrm{S}$ $37.66855^{\circ} \mathrm{E}, 513 \mathrm{~m}$ a.s.1., 20.IX.2012; $11 \mathrm{\sigma}^{7} \mathrm{\sigma}^{7}, 8$ 우, TANZANIA Morogoro, Ngerengere river, $6.83862^{\circ} \mathrm{S}, 37.66855^{\circ} \mathrm{E}, 513 \mathrm{~m}$ a.s.1., 22.IX.2012, all D. Gavryushin leg.

This crane-fly was the most abundant species of Limoniidae on the shores of Ngerengere river within the boundaries of Morogoro (not further than 1-2 km south of Madaraka Road and Jamhuri Stadium) in September. Normally the flies were observed and collected not at water's edge but resting on dry leaves or soil surface in shady places beneath the canopy of trees. While examining the specimens, I noticed a morphological character omitted or overlooked somehow by earlier authors; as far as I know it was not recorded yet for rather numerous fossil members of the genus found in amber [Kania, 2015]. That is a pair of whitish appendages on pronotum (Fig. 61), present in both sexes among examined specimens, better visible in alcoholic material. Together with the corniculus on anterior vertex, a peculiar feature shared with Toxorhina (Ceratocheilus) Wesche, 1910, cf. Tjeder
[1981], these pronotal appendages represent a good character to distinguish the subgenus Ceratolimnobia. Wing (Fig. 7), male hypopygium (Figs 62-66).

DISTRIBUTION. Madagascar, Namibia, Nigeria, South Africa, Zimbabwe, Tanzania (first record).

ACKNOWLEDGEMENTS. I would like to thank Drs. Oleg E. Kosterin (Institute of Cytology and Genetics of the Siberian Branch of the Russian Academy of Sciences, Novosibirsk, Russia) and Andrey L. Ozerov (Zoological Museum of Moscow University, Moscow, Russia) for corrections and valuable taxonomic comments, and Dr. Nikita E. Vikhrev (Zoological Museum of Moscow University, Moscow, Russia) for all the support and concern.

\section{References}

Alexander C.P. 1920. Undescribed species of African crane-flies in the collection of the British Museum (Natural History): Tipulidae, Diptera._Part I. Subfamily Limnobiinae [concl.] // Annals and Magazine of Natural History. Ser.9. Vol.6. P.336-364.

Alexander C.P. 1951. New or little-known crane-flies from Madagascar (Tipuloidea, Diptera). Part I // Mémoires de l'Institute Scientifique de Madagascar. Série A. T.5. Fasc.1. P.33-63.

Alexander C.P. 1956. Tipulidae // Ruwenzori Expedition 1934-35. Vol.1. No.7. P.129-380.

Alexander C.P. 1964. Diptera (Nematocera): Tanyderidae, Ptychopteridae, Tipulidae // South African Animal Life. Vol.10. P.229-441.

Alexander C.P. 1972. New or insufficiently known African crane flies. II. (Dipt. Tipulidae) // Studia Entomologica (N.S.). Vol.15. Fasc. $1-4$. P.385-430

Alexander C.P. 1974. New or insufficiently known African crane flies. III. (Diptera: Tipulidae) // Studia Entomologica (N.S.). Vol.17. Fasc.1-4. P.383-429.

Alexander C.P. 1976. New or insufficiently known African crane flies. V. (Diptera: Tipulidae) // Studia Entomologica (N.S.). Vol.19. Fasc.1-4. P.315-362.

Alexander C.P., Byers G.W. 1981. Tipulidae // McAlpine J.F. Peterson B.V., Shewell G.E, Teskey H.J., Vockeroth J.R., Wood D.M. (coordinators). Manual of Nearctic Diptera. Vol.1. Research Branch. Agriculture Canada. Monograph 27, Ottawa. P.153-190

Kania I. 2015. Subfamily Limoniinae Speiser, 1909 (Diptera: Limoniidae) from Baltic amber (Eocene): the genus Trichoneura Loew, 1850 // Acta zoologica cracoviensia. Vol.58. No.1. P.1-19.

McAlpine J.F. 1981. Morphology and terminology-adults // McAlpine J.F., Peterson B.V., Shewell G.E, Teskey H.J., Vockeroth J.R., Wood D.M. (coordinators). Manual of Nearctic Diptera. Volume 1. Research Branch. Agriculture Canada. Monograph 27, Ottawa. P.9-63.

Oosterbroek P. 2016. Catalogue of the Craneflies of the World ((Diptera, Tipuloidea: Pediciidae, Limoniidae, Cylindrotomidae, Tipulidae), online at: http://ccw.naturalis.nl/ (last update March 02, 2016).

Tjeder B. 1981. Limoniidae, tribe Toxorhinini (Diptera: Tipulidae) from Senegal and the Gambia // Entomologica Scandinavica. Vol.12. P.39-47. 